\title{
The 1946 magnitude 6.1 earthquake in the Valais: site- effects as contributor to the damage
}

\section{Journal Article}

Author(s):

Fritsche, Stefan; Fäh, Donat

Publication date:

2009-12

Permanent link:

https://doi.org/10.3929/ethz-b-000021268

Rights / license:

In Copyright - Non-Commercial Use Permitted

Originally published in:

Swiss Journal of Geosciences 102(3), https://doi.org/10.1007/s00015-009-1340-2 


\title{
The 1946 magnitude 6.1 earthquake in the Valais: site-effects as contributor to the damage
}

\author{
STEFAN FRITSCHE ${ }^{1} \&$ DONAT FÄH ${ }^{2}$
}

Key words: Rhone valley, seismology, history, site-effects, damage assessment, ambient vibration method, secondary effects

\begin{abstract}
The January 25, 1946 earthquake in the central Valais region in southwest Switzerland was the strongest for the last 150 years. It reached an epicentral intensity Io of VIII in the area of Sierre. The Swiss Earthquake Catalogue (ECOS 2002) assigns a moment magnitude of $\mathrm{Mw}=6.1$ to the event. Assessment of recordings from European stations resulted in a moment magnitude of 5.8 (Bernardi et al. 2005). The earthquake caused moderate to high damage within a circle of about a 25 kilometer radius. Slight damage occurred up to a distance of 200 kilometers from the epicenter.

The goal of this study was to reconstruct the damage field and consider its possible site-effects. We used an approach combining historical research with seismo-/geological investigation including a large number of experiments measuring the fundamental frequency of resonance and the shear-wave velocities of the sedimentary layers, using the characteristics of ambient vibration. This kind of research is relevant, since a huge alpine valley characterizes the Valais region, showing ground conditions that make site-effects likely for
\end{abstract}

earthquakes. While we searched for damage in an unlimited area, our investigation of site-effects was limited to the Rhone valley and to Sion and Sierre in the central Valais region in particular.

Since a contemporary damage assessment has survived in fragments only, the results of our historical investigation are incomplete. Nevertheless, it was possible to describe the losses within the epicentral region adequately enough to discuss possible site-effects. Our results show that Valaisan districts with a high percentage of settlement on the lacustrine and fluviatile deposits of the Rhone valley show higher losses than other districts. The villages of Sierre and Sion we investigated in more detail. Sion is located on compacted sediments with relatively high shear-wave velocities. The city suffered only moderate damage, rather regularly distributed. In Sierre, on the other hand, we identified two zones of significantly increased damage, in which site-effects appear a very probable contributor. Local two- or three-dimensional resonance phenomena play an important role in explaining this feature.

\section{Introduction}

\section{The earthquake series and its parameters}

It was already dark when the region of the Central Valais was hit by a strong earthquake on January 25, 1946 at 5.32 pm. In Sion, the capital city of the Valais Canton and in many other villages nearby the power supply broke down immediately. People rushing out of the houses found themselves on streets covered with rubble of destroyed chimneys, thrown off roof tiles and chipped façade pieces. For many hours, confusion reigned. Communication lines were overstrained and for some time out of order. It took several days for the extent of the consequences to become clear with respect to the event's geographical compass and severity of damage. Fortunately, the consequences appeared more minor than originally reported by newspapers within the first days after the earthquake. Although several villages sustained much damage, severe injury to persons was rare.
Three persons died from shock, a fourth was crushed by the weight of a car. A contemporary damage assessment estimates the loss related to buildings to CHF 5.265 million. This amount equals about CHF 26 million nowadays, and covers only significant damage to buildings. In addition to these losses, many secondary effects, particularly landslides, rock falls and avalanches are documented.

The 1946 event was the strongest earthquake in Switzerland for more than 150 years. However, useful instrumental data concerning this event do not exist. The few seismometers in use in Switzerland then broke down during the quake. ECOS02 (2002), the Swiss Earthquake Catalogue, thus contains only those data that rely on macroseismic observations. According to this source, the event reached an epicentral intensity of Io $=$ VIII and a magnitude of $\mathrm{Mw}=6.1$ inferred from the macroseismic field (Fäh et al. 2003). We surmise that the epicenter of the event is located at 597025/133180 (Swiss coordinates, with an uncertainty of $12 \mathrm{~km}$ ). Recordings for the same

\footnotetext{
${ }^{1}$ Swiss Seismological Service, Institute of Geophysics, Sonneggstrasse 5, 8092 Zurich, Switzerland. E-mail: stefan.fritsche@sed.ethz.ch

${ }^{2}$ Swiss Seismological Service, Institute of Geophysics, Sonneggstrasse 5, 8093 Zurich, Switzerland. E-mail: donat.faeh@sed.ethz.ch
} 
Table 1. Main- and aftershocks of the 1946 earthquake series with magnitude Mw larger than 5, verified by the Swiss Seismological Service (ECOS 2002). CHX/CH-Y: Swiss coordinates, Mw: moment magnitude, Io: epicentral intensity, Ix: maximum intensity. Of particular interest is the aftershock of May 30,1946, since it triggered a rock fall of about four to five million $\mathrm{m}^{3}$ near the Rawylhorn.

\begin{tabular}{lccccccccc}
\hline YEAR & MONTH & DAY & HOUR & MINUTE & CH-X & CH-Y & Mw & Io & Ix \\
\hline 1946 & 1 & 25 & 17 & 32 & 597.025 & 133.180 & 6,1 & 8 & 8 \\
1946 & 1 & 26 & 3 & 15 & 599.334 & 125.398 & 5,2 & 6 & 6 \\
1946 & 2 & 4 & 4 & 11 & 606.037 & 127.624 & 5,1 & 5 & 5 \\
1946 & 5 & 30 & 3 & 41 & 598.332 & 127.621 & 6 & 7 & 7 \\
\hline
\end{tabular}

region since 1975 (the start of the analog short-period network of the Swiss Seismological Service) show epicenters at shallow depth in the range of $4-10 \mathrm{~km}$. They all have a significant strikeslip component. Whether the 1946 event in fact occurred at a comparable depth and with a similar fault-mechanism remains an open question. Another assessment of moment magnitude Mw performed by Bernardi et al. (2005) rests upon amplitude measurements of regional surface waves of seismograms recorded by analog instruments in Europe, outside of Switzerland. Set at $\mathrm{Mw}=5.8$, their result for $\mathrm{Mw}$ is slightly lower than the ECOS-02 magnitude estimate. According to the yearly reports of the Swiss Earthquake Commission, the series started with two foreshocks in November 1945 (Swiss Earthquake Commission 1945). The stronger of these two shocks occurred on November 10 and reached an intensity of V (Rossi-Forel). On November 13 another shock with I= IV (Rossi-Forel) was observed. The assigned epicentral regions for these two events correspond with ECOS data concerning the main shock of January 25,1946 . With respect to immediate aftershocks, the reports of the Swiss Earthquake Commission (1946-1949) are not complete, as declared in a personal note at the beginning of the report. Since the seismographs were not operational before $9 \mathrm{pm}$ on January 25, the report mentions a recording gap of about 3 hours. Moreover, the report of the Swiss Earthquake Commission is also incomplete for the following months and years. Comparison with a later publication of Wanner (then head of the Swiss Earthquake Commission) \& Grütter (1950), shows that the commission considered only a few of the aftershocks in the official report. Among them were three strong aftershocks (Tab. 1) and several minor shocks. This publication by Wanner \& Grütter (1950), lists a total of 517 aftershocks for the year 1946, 44 aftershocks for 1947, 31 for 1948 and 21 for 1949 (Tab. 2). Regrettably, the list contains no information concerning the related intensities. However, we expect that all events were felt and have intensities Io smaller than intensity V. Exceptions are the aftershocks listed in Table 1.

It is interesting to see (Table 2) that earthquake activity was very low from 1900 until the end of 1945. For several years, the aftershock activity remained high, decreasing slowly toward the nineteen fifties. Whether the two mentioned events in November 1945 actually have to be rated as foreshocks is not traceable. However, it is apparent that no immediate foreshock occurred that would have warned the population (Swiss Earthquake Commission 1945). Likewise, such a pattern was also
Table 2. Monthly frequency of earthquakes in the epicentral region of the 1946 earthquake from 1900 until 1950 (Wanner \& Grütter1950). The dataset is incomplete for the year 1950, see Wanner (1955) for the continuation of the time series.

\begin{tabular}{|c|c|c|c|c|c|c|c|c|c|c|c|c|c|}
\hline \multirow[b]{3}{*}{ Ánnées } & \multicolumn{13}{|c|}{ TABELLE I } \\
\hline & \multicolumn{13}{|c|}{$\begin{array}{l}\text { Fréquence mensuelle des secousses dans la région épicentrale } \\
\text { pour la période } 1900-1950\end{array}$} \\
\hline & I & II & III & IV & $\mathrm{v}$ & VI & VII & JIII & IX & $\mathrm{x}$ & $\mathrm{XI}$ & $\mathrm{XII}$ & Annie \\
\hline 1900 & - & - & - & - & - & - & - & - & - & - & - & - & - \\
\hline 1901 & - & - & - & - & - & - & - & - & - & - & - & - & 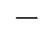 \\
\hline 1902 & - & - & - & - & - & - & - & - & - & - & - & - & -- \\
\hline 1903 & - & - & - & 2 & - & - & - & - & 1 & - & - & - & 3 \\
\hline 1904 & - & - & - & - & - & - & - & - & - & - & - & - & - \\
\hline 1905 & - & - & - & - & - & - & - & - & - & - & - & - & - \\
\hline 1906 & - & - & - & - & - & - & - & - & - & - & - & - & - \\
\hline 1907 & - & - & - & - & - & - & - & - & - & - & - & - & - \\
\hline 1908 & - & - & - & -. & - & - & - & - & - & - & - & - & - \\
\hline 1909 & - & - & 1 & - & - & - & - & - & 1 & - & - & 1 & 3 \\
\hline 1910 & 1 & - & - & - & - & - & - & - & - & - & - & - & 1 \\
\hline 1911 & 1 & - & - & - & - & - & - & - & - & - & - & - & 1 \\
\hline 1912 & 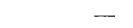 & - & - & - & - & - & - & - & - & - & - & - & - \\
\hline 1913 & - & - & - & - & - & - & - & - & - & - & - & - & - \\
\hline 1914 & - & - & - & 4 & 1 & - & - & - & - & - & - & - & 5 \\
\hline 1915 & - & - & - & - & - & 1 & - & 2 & - & 6 & - & - & 9 \\
\hline 1916 & - & - & - & 1 & - & - & - & 1 & - & - & - & - & 1 \\
\hline 1917 & - & - & - & - & - & 1 & - & - & - & - & - & - & 1 \\
\hline 1918 & - & 2 & - & - & - & - & 3 & - & - & - & - & - & 5 \\
\hline 1919 & - & 1 & - & - & - & 1 & - & - & 1 & - & 1 & - & 4 \\
\hline 1920 & - & - & 8 & 9 & - & - & - & - & - & 1 & - & - & 18 \\
\hline 1921 & - & 1 & - & 3 & 2 & - & - & - & - & - & - & - & 6 \\
\hline $\begin{array}{l}1922 \\
\end{array}$ & $\overline{-}$ & - & $\overline{-}$ & - & - & $=$ & $\overline{-}$ & - & - & - & 8 & - & 8 \\
\hline 1923 & - & - & - & - & - & - & - & - & - & - & - & - & \\
\hline 1924 & - & - & - & - & - & - & - & - & - & 1 & 1 & - & 2 \\
\hline $\begin{array}{l}1925 \\
\end{array}$ & - & - & - & - & - & - & - & - & - & - & 1 & - & 1 \\
\hline 1926 & - & - & - & - & - & - & - & 1 & - & - & 1 & - & 2 \\
\hline 1927 & - & - & - & - & - & - & - & - & - & - & - & - & - \\
\hline 1928 & -. & - & - & - & - & - & - & - & - & - & - & - & - \\
\hline $\begin{array}{l}1929 \\
\end{array}$ & - & - & - & - & - & - & - & - & - & - & 1 & 11 & 12 \\
\hline 1930 & 2 & 1 & - & - & 6 & - & - & - & - & - & - & - & 9 \\
\hline 1931 & - & - & - & 1 & - & - & 2 & 1 & - & 1 & - & - & 5 \\
\hline 1932 & - & - & - & - & 3 & - & - & - & - & - & - & - & 3 \\
\hline 1933 & -- & - & - & - & - & - & - & - & - & - & - & - & - \\
\hline 1934 & - & - & - & - & - & - & - & - & - & - & 1 & - & 1 \\
\hline 1935 & - & - & - & - & - & - & - & - & - & - & - & - & - \\
\hline 1936 & -- & - & - & - & - & - & - & - & - & - & - & - & - \\
\hline 1937 & - & - & - & - & - & - & - & - & -- & - & 1 & 1 & 2 \\
\hline 1938 & - & - & - & - & - & - & - & - & - & 1 & 1 & & 2 \\
\hline 1939 & 1 & - & - & - & - & - & - & - & - & 1 & 3 & 2 & 7 \\
\hline & $\ldots$ & - & - & - & - & - & - & - & - & - & - & - & - \\
\hline 1941 & - & - & - & - & - & - & - & - & - & - & - & - & - \\
\hline 1942 & - & - & - & - &.- & - & - & - & - & - & - & - & - \\
\hline 19 & - & - & - & - & - & - & - & - & - & - & - & - & - \\
\hline 1944 & - & - & - & - & - & - & 1 & - & - & - & - & - & 1 \\
\hline 1945 & - & - & - & - & - & - & - & - & - & - & 2 & - & 2 \\
\hline $\begin{array}{l}1946 \\
\text { S }\end{array}$ & $145^{\circ}$ & 108 & 73 & 21 & 59 & 51 & 24 & $\overline{17}$ & 10 & 2 & 1 & & 517 \\
\hline 1947 & 4 & 1 & 5 & 1 & & 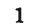 & 19 & 0 & 4 & 3 & 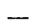 & 4 & 44 \\
\hline 194 & 2 & $i$ & 1 & 2 & 1 & 2 & 3 & & 6 & 1 & 8 & 4 & 31 \\
\hline 194 & 1 & 2 & 4 & - & 1 & 1 & 2 & & 0 & 5 & $\div$ & 1 & 21 \\
\hline 1950 & 1 & 1 & - & 3 & - & 1 & 1 & 4 & 2 & - & - & - & - \\
\hline
\end{tabular}

characteristic for the 1855 earthquake series in the upper Valais region. It started with a sudden main shock with Io=VIII followed by a long lasting series of aftershocks until the end of the decade (Fritsche et al. 2006). In contrast, the 1755 earthquake 


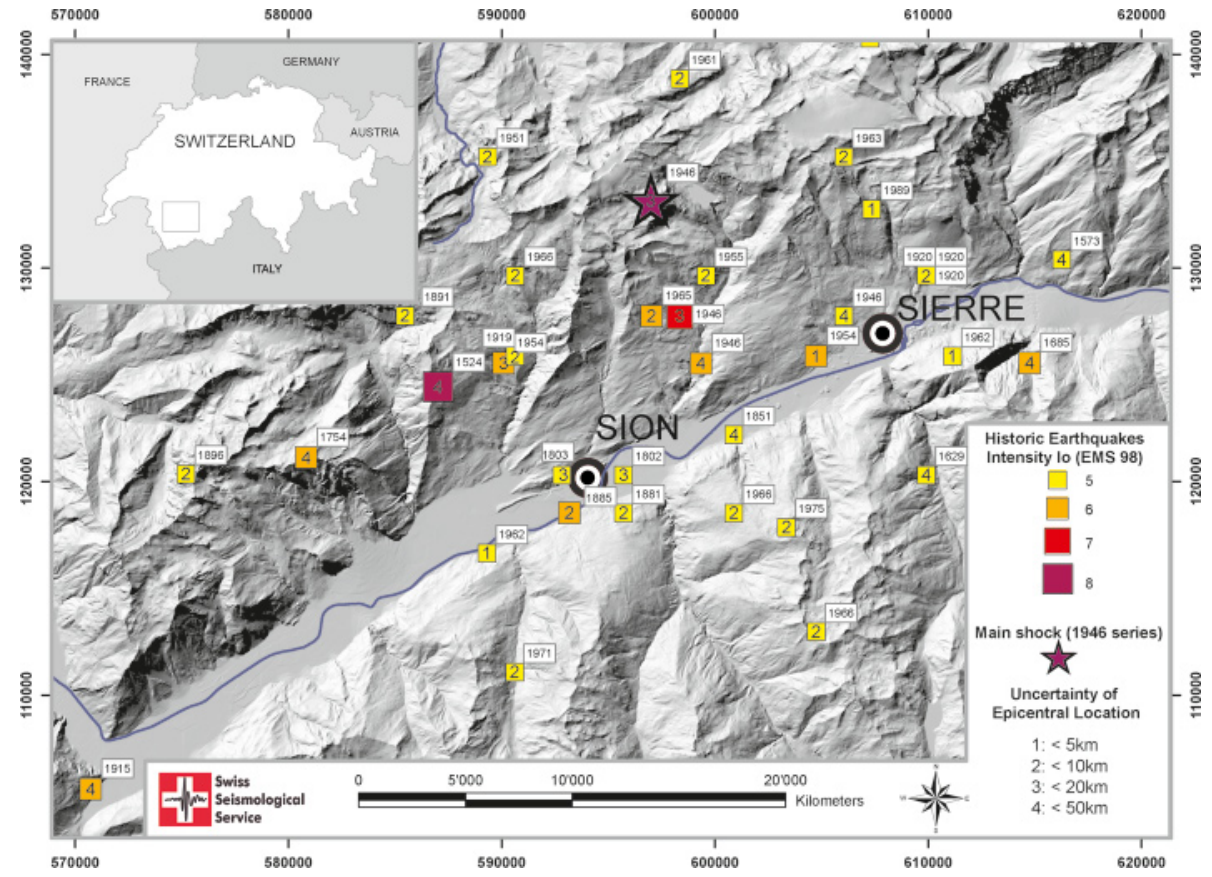

Fig. 1. Historic seismicity of the middle Valais region based on ECOS-02 data (Swiss Seismological Service, 2002) with Io $\geq 5$.: Intensity, epicenter, and uncertainty of the epicentral location. series that had its epicenter close to the 1855 event, started with an immediate foreshock so that people left their houses (Gisler 2004). It was followed by a main shock of intensity VIII and about 30 aftershocks within the next year (ECOS 2002).

\section{Historical Seismicity of the Valais Region}

The Valais is the area of largest seismic hazard in Switzerland and has experienced a magnitude 6 or larger event every 100 years $(1524,1584,1685,1755,1855,1946)$. See Fritsche et al. (2006) for the 1855 event and Gisler et al. (2004) for the 1755 earthquake. Damaging earthquakes occur about every 30-40 years (Intensity VI-VIII), with the last in 1960 close to Brig. During all such events significant damage occurred from ground motion and different kinds of secondary phenomena such as liquefaction in the Rhone plain, slope instabilities and extended rock fall. Historical investigation has shown that the intervals between the earthquakes remained impressively constant for historically traceable time. Figure 1 shows the historic seismicity of the middle Valais region.

\section{Significance of site-effect investigations for the Valais region}

What changed considerably during the last century is the use of the land in this region. It is characterized by a large alpine valley more than $100 \mathrm{~km}$ in length and a valley floor with a width of up to $5 \mathrm{~km}$. This valley floor was not usable for the most part until a comprehensive river correction of the Rhone took place in the 19th and 20th century. Thus, the traditional villages and cities were built either on the valley's slope or on debris cones of tributary rivers, safe from recurring inundations. With the straightening and canalization of the Rhone River, the bottom of the valley became interesting for settlement and industrial purpose. Particularly the decades after World War II show a strong and disproportionately high increase of buildings and infrastructure built there (see Fig. 2) compared to the Valais region in general. Since the valley floor shows ground conditions that make site-effects likely for wide areas, the seismic risk increases remarkably for this ongoing period. Although empirical observations are absent due to relatively weak seismic activity during the last 40 years, it is thus assumed that an event similar to the 1946 earthquake would cause significantly higher damage than observed in the past.

In this paper, we present the findings of our historical investigation into the damage field of the 1946 event and the results of field experiments carried out in the cities of Sion and Sierre. We start with an overview characterizing the entire damage field within the Valais Canton. Then we will proceed with case studies concerning Sion and Sierre. Both show interesting ground conditions with respect to potential site-effects as well as a large number of damaged buildings after the 1946 earthquake. Our main goal was to answer whether site-effects influenced the damage field of the 1946 earthquake.

\section{Methodology}

We combined historical investigation with seismo-geological research, starting with the evaluation of the damage field. Investigation of a large number of historical documents of different types allowed a good qualitative description of the losses within the whole damage field. Most important for this task were newspaper articles. We studied several dozen newspa- 


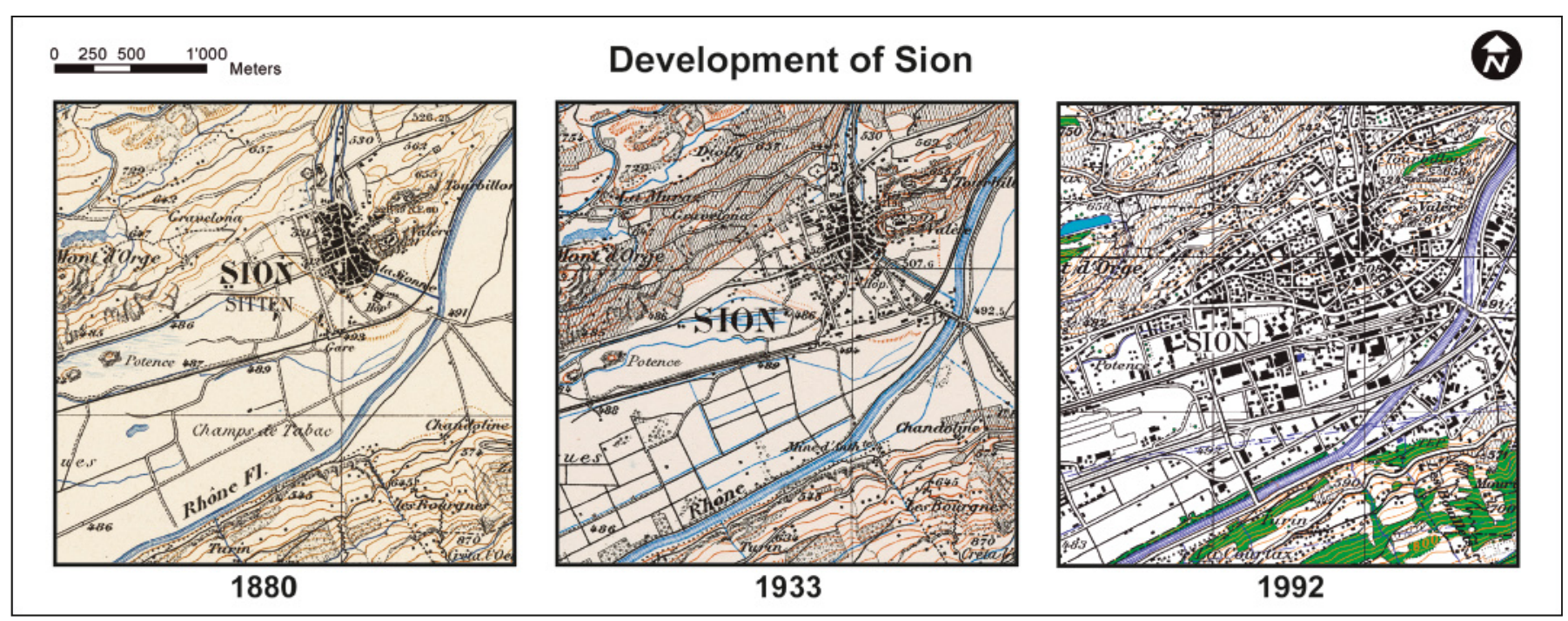

Fig. 2. Development of Sion from the eighteen-eighties to the nineteen-nineties on historic maps $\left(1: 50^{\prime} 000\right)$. The figure shows the impressive and still ongoing increase of the city toward the bottom of the Valaisan main valley. From left to right: first and last edition of the Siegfried map (no. 486) and a map of the Federal Office of Topography showing Sion in 1992 (Swiss Map 25, no. 1306)

pers of the affected region and all newspapers with nationwide importance (see bibliography Fritsche 2008). Further sources of significance were contemporary scientific journal articles (Wanner \& Grütter 1950; Wanner 1955; Montadon 1946; Montadon \& Staub 1946; Marietan 1946; Marietan 1947), the mentioned reports of the Swiss Earthquake Commission (Swiss Earthquake Commission 1940-1950) and documents that gave insights into the cantonal council meetings of the respective time (StAW, Protocoles des séances du Conseil d'État 1946). Unfortunately, a damage assessment on behalf of the government of the Valais Canton is of lower value than expected, since only a few summary numbers and amounts of money are known from it via newspaper articles. The damage assessment itself is untraceable at this time. A quantitative analysis of the losses was thus incomplete. Newspaper articles don't guarantee for completeness, especially concerning damage of reduced importance. An assessment for individual buildings following the guidelines of European Macroseismic Scale (EMS 98) (Grünthal 1998) was only practicable for buildings showing remarkable damage. But for the cities of Sion and Sierre our understanding is relatively good, when compared with other places. While studying historical sources, we also focused on observations related to secondary phenomena. Besides the well-known rockslide at the Rawylhorn, we identified almost 90 smaller landslides, rock falls, avalanches, and other effects that were triggered by the earthquake of January 25, 1946 and its aftershocks. (Fig. 6, Table 6)

This first step of historical research was followed by investigation of ground conditions at the two sites. For this purpose, we studied the regional geology and carried out field experiments to evaluate the fundamental frequency of resonance at a large number of sites. We investigated ambient vibration $\mathrm{H} / \mathrm{V}$ spectral ratios. In total, we recorded ambient vibration at
190 sites (75 in Sion, 115 in Sierre) for 20 minutes each and computed the $\mathrm{H} / \mathrm{V}$ spectral ratios according to algorithms described by Fäh et al. (2001). Two methods were applied to compute average $\mathrm{H} / \mathrm{V}$ ratios. The first is classical polarization analysis in the frequency domain, where polarization is defined as 'the ratio between the quadratic mean of the Fourier spectra of the horizontal components and the spectrum of the vertical component.' We assume that the vertical component in the frequency band of interest close to the $\mathrm{H} / \mathrm{V}$ peak is dominated by the Rayleigh wave. The SH-part of the wavefield contributes to the horizontal component of motion in the measurements. If the SH-part is removed, the $\mathrm{H} / \mathrm{V}$ ratios would better determine the ellipticity of the fundamental mode Rayleigh wave. This removal requires some assumptions concerning the spectral content of SH-waves. Generally, we assume that the radial component (Rayleigh waves) is equal in amplitude to the transverse (Love waves), and the amplitude of the $\mathrm{H} / \mathrm{V}$ spectral ratio can then be reduced by $\log 10(\operatorname{sqrt}(2))$ when the $\mathrm{H} / \mathrm{V}$ amplitude is given in a logarithmic scale.

The second method for H/V ratios tries to reduce the SHwave influence by identifying P-SV-wavelets from the signal and taking the spectral ratio from them only. This is done by means of a frequency-time analysis (FTAN) on each of the three components of the ambient vibrations. In a frequency-time representation of the vertical signal, the most energetic sections are identified in time for each frequency. We assume that this maximum is related to a single P-SV wavelet for which the H/V ratio is computed. The average over all wavelets defines the H/V spectral ratio. For more details we refer to Fäh et al. (2001).

In addition, we computed the quality of the peak, for all maxima identified in the H/V spectral ratio (see Fig. 3). This quality is defined as the average value of 2 quality measures as follows:

426 S. Fritsche \& D. Fäh 


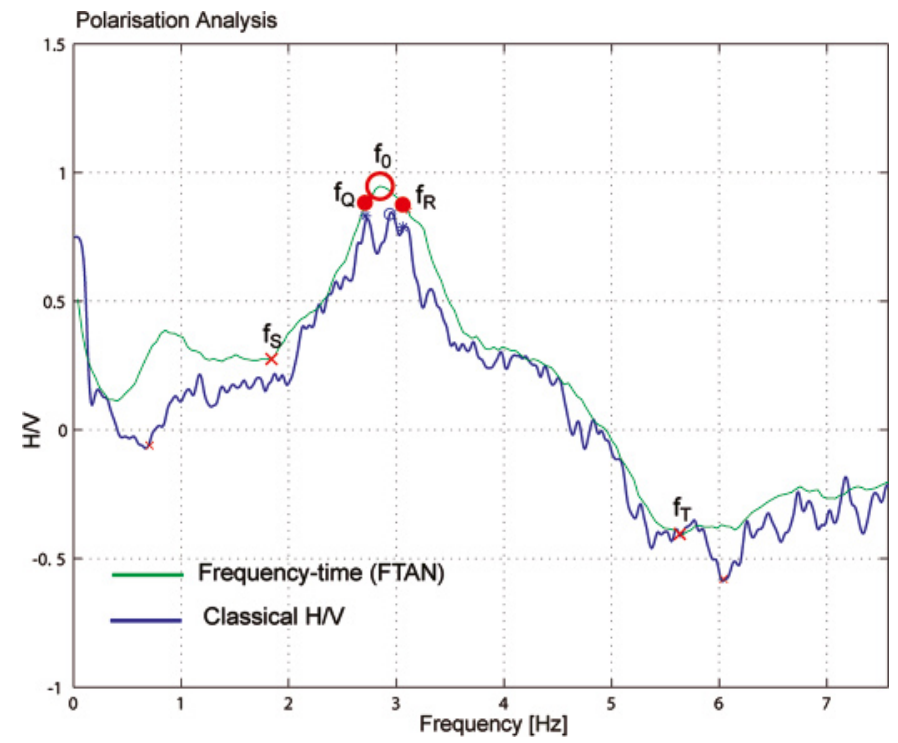

Fig. 3. Theoretical example of an $\mathrm{H} / \mathrm{V}$ spectrum including the definition of the frequencies $\mathrm{f}_{0}, \mathrm{f}_{\mathrm{S}}, \mathrm{f}_{\mathrm{Q}}, \mathrm{f}_{\mathrm{R}}$ and $\mathrm{f}_{\mathrm{T}}$.

$Q=\frac{\left(Q_{1}+Q_{2}\right)}{2}$

applied to the H/V curve obtained with the FTAN method.

The following definitions are used:

$\mathrm{f}_{0}$ : $\quad$ Frequency of the H/V-peak= Fundamental frequency of resonance

$\left[\mathrm{f}_{\mathrm{Q}}, \mathrm{f}_{\mathrm{R}}\right]$ : Uncertainty range of the fundamental frequency of resonance

$\mathrm{f}_{\mathrm{s}}$ : $\quad$ Frequency of the first minimum to the left of the H/Vpeak

$\mathrm{f}_{\mathrm{T}}$ : $\quad$ Frequency of the first minimum to the right of the H/Vpeak

The first quality measure of the peak (Q1) is defined as follows:

$Q_{1}=\frac{\int_{f_{Q}}^{f_{R}} \log 10\left(\frac{H}{V}\right) d f}{\left(f_{R}-\mathrm{f}_{\mathrm{Q}}\right)}-\frac{\log 10\left(\frac{H}{V}\left(f_{S}\right)\right)+\log 10\left(\frac{H}{V}\left(f_{T}\right)\right)}{2}$

The second quality measure of the peak $(\mathrm{Q} 2)$ is:

$Q_{2}=1+\frac{\int_{f_{S}}^{f_{T}} 10^{\left|\log 10\left(\frac{H}{V}\right)-\bar{A}\right|} d f}{\left(f_{T}-f_{S}\right)}$

$\bar{A}=\frac{\int_{f_{S}}^{f_{T}} \log 10\left(\frac{H}{V}\right) d f}{\left(f_{T}-f_{S}\right)}$

The quality of the peak is not a quantitative measure of expected amplification, but provides a qualitative description of the impedance contrast between sediments and bedrock. Finally, we included the results from ambient vibration array measurements in our site investigation. These measurements allow a characterization of the sedimentary cover in terms of shear wave velocity as a function of depth. The array method we use is based on the high-resolution frequency wave number estimator or high-resolution beam-forming (HRBF). It was originally proposed by Capon (1969) and further developed by Kind et al. (2005) and Fäh et al. (2008).

\section{Results of the historical investigation}

\section{Macroseismic field and damage}

The earthquake of January 25, 1946 was felt in an area with a radius of more than 250 kilometers. While coverage with macroseismic data is dense and substantial for Switzerland (ECOS 2002) and France (BRGM, EDF \& IRSN), data for Italy is sparse, and for Germany and Austria almost absent. Macroseismic data points showing intensity of grade VI and larger (building damage) concentrate in the southwestern part of Switzerland (Fig. 4). Serious damage was observed in the Valais Canton and to a much lesser extent in the neighboring cantons of Bern (to the north) and Vaud (to the west). In the Valais, the high intensities (VII-VIII) were observed in the villages and cities of the Rhone valley.

A systematic assessment of the losses in the weeks after the earthquake covers only Valais Canton. As mentioned, the relevant documents are lost. All we know rests on a newspaper article that summarizes some data. Furthermore, we know almost nothing about the regulations that ruled this survey. Nevertheless, in combination with statistical data of the census accomplished in 1941 (Bureau Fédéral de Statistique 1946), a few statements are possible. Tables 3 and 4 review the known data of the assessment. They are not fully consistent, as a summation of the partial amount shows (compare the total damage costs given in Tables 3 and 4 as well as the cost assigned to the two building categories in Table 3). We don't know whether these are errors or rather a consequence of the approach used for the damage assessment. However, for the calculations shown here the differences have minor impact.

In total 3485 buildings suffered damage. By far the largest part of the assessed loss relates to damage to residential buildings (about $85 \%$ ). The remaining $15 \%$ concerns public buildings, churches, and schools. This simple classification reveals that industrial buildings and buildings with an agricultural purpose probably were overlooked in the course of the assessment. An interpretation of this data is delicate, since we don't even know how many of the damaged buildings belong to which of the two classes. Assuming that the number of public buildings, churches, and schoolhouses must have been small when compared to residential buildings (we estimate that this building category makes about $5 \%$ of the assessed buildings), we can conclude that almost every sixth residential building of the Valais Canton suffered damage. The average loss per dam- 


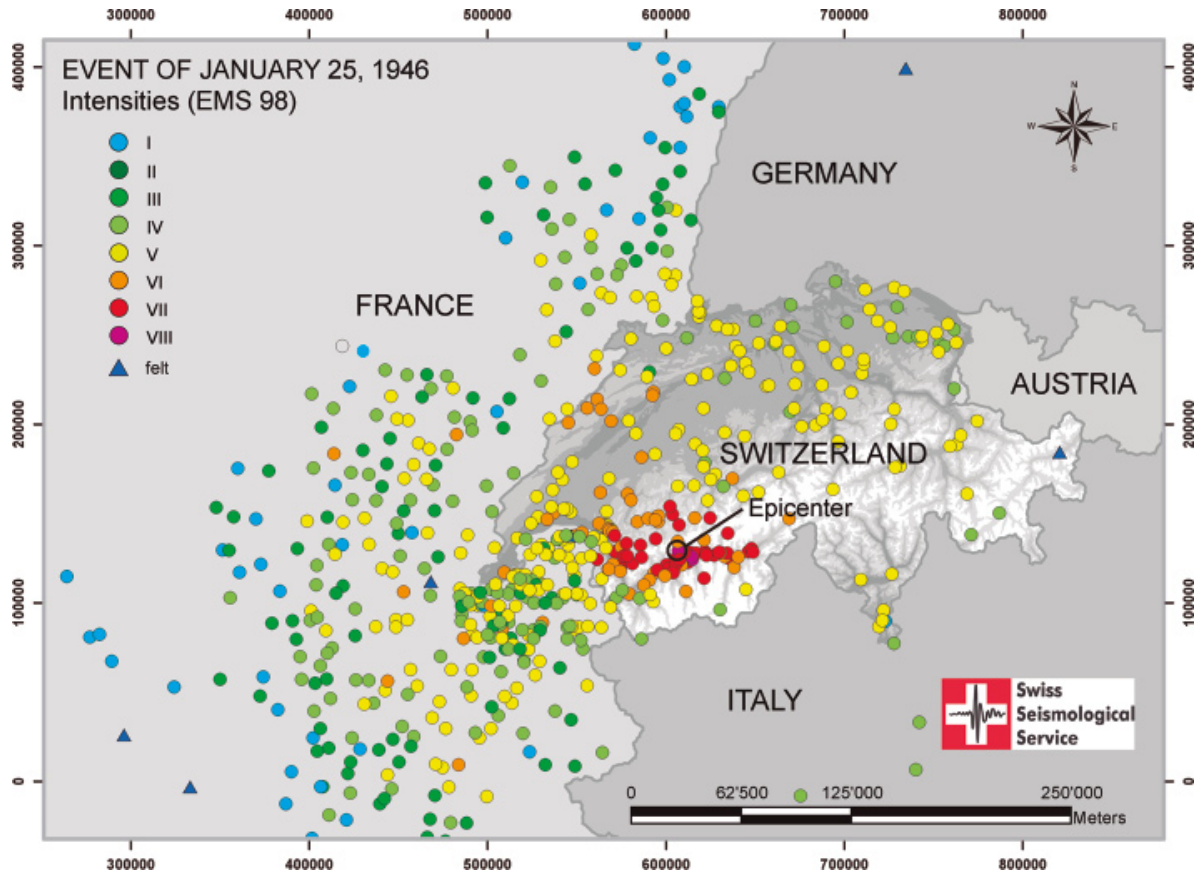

Fig. 4. Macroseismic map of the January 25, 1946 event based on ECOS-02 data (Swiss Seismological Service 2002) and data from the French catalogue Sis France (BRGM et al. 2005).

aged building within the residential building class thus equals an amount of CHF 1314.-, That corresponds to about CHF 6400.- today, taking into account inflation.

In addition to the data summarized in Table 3, the newspaper article discussing the damage assessment includes rudimentary information on the geographical distribution of the loss. Valais Canton consists of 14 districts for which the article mentions the total loss in CHF (Walliser Nachrichten 1946). The total number of then existing residential buildings we extracted from the mentioned statistics (Bureau Fédéral de Statistique 1946). Assuming that the proportion of residential buildings and the building class consisting of public buildings, churches and schoolhouses is about the same for all districts $(95 \%$ to $5 \%$ ), we can calculate an average loss per "assessed building and district." In addition to this value, we estimated the portion

Table 3. Summary of the lost original contemporary damage assessment, done on behalf of the Valaisan government in 1946 (Walliser Nachrichten 14. 5.1946). The total number of existing residential houses in 1946 rests upon data from the Bureau Fédéral de Statistique (1946). The inflation-adjusted amount in $\mathrm{CHF}$ is based on data available via http://www.portalstat.admin. ch/lik_rechner/d/lik_rechner.htm

Assessed damage in CHF (2006) approx.:

Assessed damage in CHF (1946):

Damage on public buildings, churches and schoolhouses:

Damage on residential buildings:

Total number of residential buildings:

Number of damaged buildigs:

\section{6'000'000.-}

5'265'345.-

850 '130.-

4'351'880.-

$21^{\prime} 744$

3'485 of buildings per district built on the plain of the main valley at the time of the earthquake, where we expect higher amplification during ground shaking. This has been done on the basis of contemporary maps, where we decided for each village of a district whether it is located on the bottom of the main valley or not. For most cases, decision-making was easy and we could assign the villages to one of the two categories. In those villages only partly built on the sediments of the valley floor, we took only a corresponding number of buildings into account. Comparison of the results of this calculation is given in Figure 5. The background shows a zoomed view of the macroseismic map (Fig. 4).

Not surprisingly, the highest values are related to the districts nearest the epicenter. Sierre shows by far the maximum loss per building with CHF 1071.-- It is followed by the district of Sion (CHF 484.-) and Hérens (CHF 206.-). In general, the values decrease with distance to the east and west. However, we can recognize certain variations. Brig (to the east), for example, shows a higher value (CHF 48.-) than Visp (CHF 20.-) or Westlich Raron (CHF 25.-), although the latter are closer to the epicenter. Entremont finally (to the southwest) shows clearly lower losses (CHF 1.-) than its neighboring districts. Martigny (CHF 6.-) with a high portion of buildings located on the valley floor sticks out through its low value in comparison with Conthey (CHF 68.-) or Saint-Maurice (CHF 24.-). An explanation for these findings is fragile since they rest upon rudimentary data. However, it is evident that the average loss is strongly affected by the portion of buildings located on the sediments of the Rhone valley. Brig in this regard shows a high portion of buildings located in the main valley $(60 \%)$ as well as a high average loss per building (CHF 48.-) compared with

428 S. Fritsche \& D. Fäh 


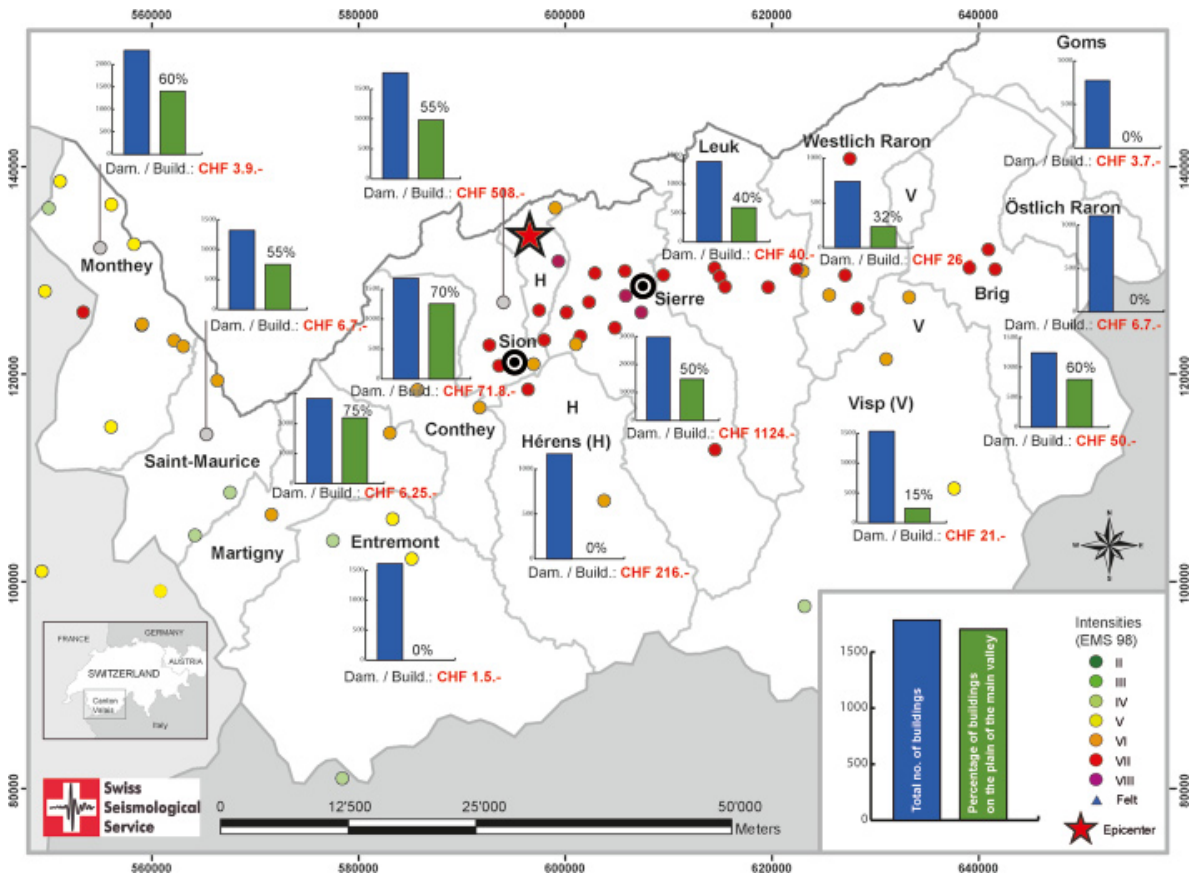

Fig. 5. Distribution of the loss per district in Valais Canton, together with the macroseismic intensity data points. The loss per building and district in CHF (red number) rests upon data of the lost damage assessment (Walliser Nachrichten 1946). The numbers of existing buildings rely on data from the Bureau Fédéral de Statistique (1946). The percentage of buildings located on the plain of the main valley is an estimation based on maps (Topographischer Atlas der Schweiz, Kartenblätter $476,477,481,482,483,485,486,487,496,497$, $526,527,2003 \mathrm{~b}$ and the mentioned data collection.
Westlich Raron (32\%, CHF 26.-) and Visp (15\%, CHF 21.-). Entremont, located completely on the mountainside without settlements in the main valley, shows an average loss clearly below its neighboring districts (CHF 1.50).

We note two explanations for this phenomenon. First, the bottom of the main valley shows unfavorable ground conditions. These consist of poorly consolidated sediment deposits of a thickness up to 1000 meters (Rosselli 2001). Roten (2007) showed with recorded data and numerical simulations for the region of Sion that these lacustrine and fluviatile sediments have a large potential for amplification effects. Fritsche et al. (2006) pointed out in the context of the 1855 earthquake in the Visp region that several villages in the main valley showed high intensities and remarkable damage compared with settlements on the mountainside. Thus it is probable that for the 1946 earthquake, districts with a large portion of buildings located on the bottom of the main valley suffered higher loss. A second explanation refers to building vulnerability. Although systematic data about the building stock does not exist for the respective decades of the $20^{\text {th }}$ century, qualitative investigations have shown (Fritsche 2006) that in the relevant region buildings on the mountainside tend to construction in timber. In contrast, the villages and cities in the main valley show to a much higher degree structures of simple stone, massive stone or brick: more vulnerable to ground shaking. Over all, a combination of the influence of ground conditions and building vulnerability is a likely and reasonable explanation for the findings. Not explainable, however, is the strong decrease in loss per building from the district of Conthey (CHF 68.-) to the Martigny district (CHF 6.-), particularly because both show comparable portions of buildings located on the plain of the main valley.
Table 4. Loss per district in CHF (Walliser Nachrichten 14. 5.1946), portion of buildings on valley floor and average loss per building.

\begin{tabular}{lccr}
\hline District & $\begin{array}{c}\text { Buildings on } \\
\text { valley floor (\%) }\end{array}$ & $\begin{array}{c}\text { Average loss per } \\
\text { building (CHF) }\end{array}$ & $\begin{array}{c}\text { Total loss } \\
\text { (CHF) }\end{array}$ \\
\hline Brig & 60 & $48 .-$ & $62^{\prime} 300 .-$ \\
Conthey & 70 & $68 .-$ & $120^{\prime} 875 .-$ \\
Entremont & 0 & $1 .-$ & $2^{\prime} 450 .-$ \\
Goms & 0 & $4 .-$ & $2^{\prime} 900 .-$ \\
Hérens & 0 & $206 .-$ & $252^{\prime} 930 .-$ \\
Leuk & 40 & $382 .-$ & $557^{\prime} 420 .-$ \\
Martigny & 75 & $6 .-$ & $17^{\prime} 950 .-$ \\
Monthey & 60 & $4 .-$ & $9^{\prime} 000 .-$ \\
Westlich Raron & 32 & $25 .-$ & $19^{\prime} 200 .-$ \\
Östlich Raron & 0 & $2 .-$ & $2^{\prime} 450 .-$ \\
St. Maurice & 55 & $24 .-$ & $33^{\prime} 060 .-$ \\
Sierre & 50 & $1^{\prime} 071 .-$ & $3^{\prime} 351^{\prime} 880 .-$ \\
Sion & 55 & $484 .-$ & $900^{\prime} 140 .-$ \\
Visp & 15 & $20 .-$ & $32^{\prime} 720 .-$ \\
\hline
\end{tabular}

Source radiation or directivity effects could be an explanation. The decrease from Sion (CHF 484.-) to Conthey, however, is of similar size, but on a higher level.

Despite systematic investigation of several dozens of different newspapers and other potential sources, we are still disappointed in our information about damage to individual buildings Table 5). In total, we could evaluate the damage to 167 buildings. For 105 of these buildings we identified the exact location. With respect to Valais Canton, we identified 121 damaged buildings and know the exact location for 65 of them. For 


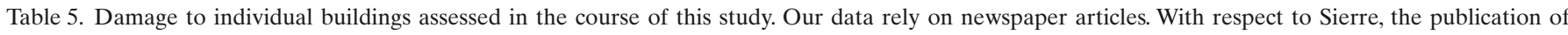
Wanner (1950) was a useful source. Not all buildings could be located accurately.

\begin{tabular}{|c|c|c|c|c|c|c|}
\hline Verified cases of damage: & of Grade 1 & of Grade 2 & of Grade 3 & of Grade 4 & total & thereof localised \\
\hline Within the Valais Canton & 9 & 43 & 55 & 14 & 121 & 65 \\
\hline Outside the Valais Canton & 3 & 32 & 11 & 0 & 46 & 40 \\
\hline Total & 12 & 75 & 66 & 14 & 167 & 105 \\
\hline
\end{tabular}

another 35 damaged buildings, we know their position, without having information concerning the kind of damage (See the paragraph related to the village of Sierre).

\section{Secondary Effects}

Our historical investigation also considered secondary effects. In total 88 observations have been verified (Table 6). Sixtythree of these arose from the main shock of January 25, 1946. The remaining 25 observed secondary effects occurred in the course of the strong aftershock of May 30, 1946. About 90\% of these data rely on newspaper articles. The others rest upon a document of the cantonal Administration and other sources. See Fritsche (2008) for bibliography and further information. Most of these effects occurred in a circle of about 20 kilometers diameter around the epicenter.

Almost all effects took place north of the Rhone valley, in the fault zone (Fig. 6). Table 6 summarizes the observations in groups of comparable types of effect and assigns them to the main or to the mentioned aftershock. The class of "large rock fall" consists of two events that occurred at the Rawylhorn. That of May 30 was of remarkable dimensions. Wanner and Grütter (1950) write of 4-5 million cubic meters of stone that overwhelmed a small lake and a mountain pasture. The large rock fall of January 25 also had severe consequences since it destroyed a couple of mountain huts, pastures, and parts of a forest. The class of "rock fall" in contrast describes events of smaller dimensions, from a few boulders that fell down to rock falls of several hundred cubic meters of material. Of similar dimensions were the events summarized in the landslide class. Some of them de-

Table 6. Secondary effects observed in the course of the 1946 earthquake series.

\begin{tabular}{lccc}
\hline Secondary effects & \multicolumn{3}{c}{ Number of effects } \\
\cline { 2 - 4 } & January 25 & May 30 & Total \\
\hline Large rockfalls & 1 & 1 & 2 \\
Rockfalls & 20 & 21 & 41 \\
Landslides & 11 & 3 & 14 \\
Cracks in the ground & 6 & 0 & 6 \\
Terrain changes & 6 & 0 & 6 \\
Avalanches & 4 & 0 & 4 \\
Effects on springs & 11 & 0 & 11 \\
Visual phenomena & 4 & 0 & 4 \\
Total & 63 & 25 & 88 \\
\hline
\end{tabular}

stroyed or overwhelmed roads (near Leukerbad, Ayent, Gampel, in the Val d'Anniviers). Another interrupted the railways near Aigle. The observed cracks in the ground are probably of minor extent. Some of them occurred on the bottom of the main valley (e.g. in Granges near Sierre), others on the mountainside. We could not find a location for all observations of this type. The class of terrain changes is particularly interesting. It includes a collapsed road at the shore of Lake Geneva near Villeneuve, a partly caved-in coal mine near Grone ( 8 kilometers to the southwest of Sierre) and terrain changes on the sides of the Rhone channel at the same location. Avalanches were triggered on January 25 only. Many of them were observed in the massif of Les Diablerets, in the Valley of Lötschen (20 kilometers to the northeast of Sierre) and between Brig and Domodossola (Italy), where they spilled onto the railways at several locations. Effects on springs occurred in a radius more than 40 kilometers from the epicenter. Particularly frequent were observations in the region between Sierre and Visp where the flow conditions and the water temperature of several sources changed or new sources emerged (Bund, February 2, 1946; Oberländer Tagblatt, January 28, 1946). Interesting to note is that the huge subterranean lake (of $6000 \mathrm{~m}^{2}$ surface) near St. Leonard in the same region lost a lot of water after the main shock. The lake is situated in the northern slope of the Rhone Valley where it has formed in a layer of gypsum from water circulation over a long period. After the earthquake, water leaked through small fissures into the ground for a certain time (Lac souterrain 2008). Finally, we found some reports of optical phenomena. They all describe observations of an enlightened sky by "fire" or thunderbolts in an unspecific way.

\section{Site investigations and damage distributions for Sion and Sierre}

\section{Sion}

In the nineteen forties Sion was a small town with a population of hardly 10'000 persons. It consisted of a medieval center surrounded by a less dense belt of buildings originating mostly in the $19^{\text {th }}$ and $20^{\text {th }}$ centuries (Fig. 7). Comparison with Figure 2 shows how remarkably the city developed over the last six decades. The buildings of the medieval center consist of simple stone structures in large part and have two to four floors. The few public buildings mostly of massive stone have up to four floors. Building vulnerability thus is relatively high in general. Vulnerability Class B according to EMS 98 (Grünthal 1998) is

430 S. Fritsche \& D. Fäh 


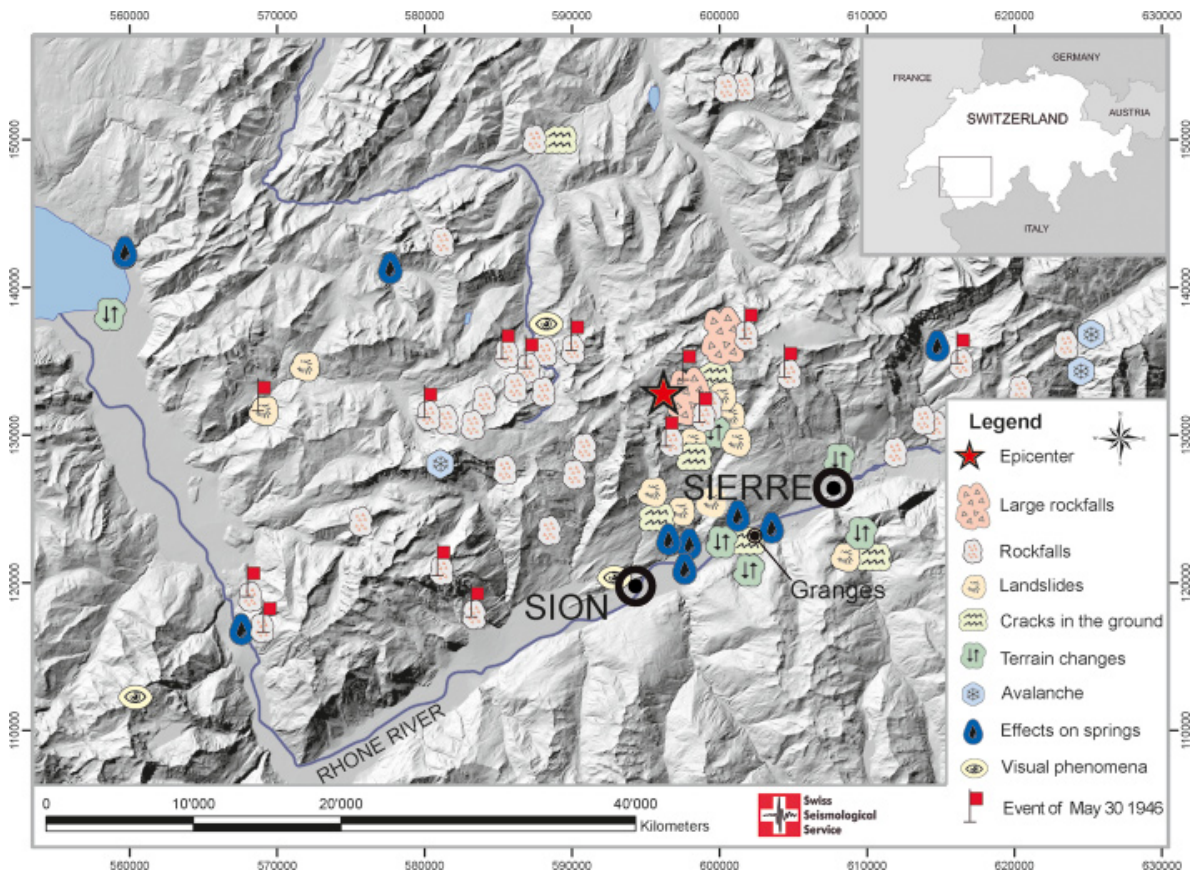

Fig. 6. Seismo-geological effects observed in the Valais and the neighboring cantons. The figure includes effects which occurred during the main shock as well as in consequence of the aftershock of May 30,1946. probably a good assumption for most of the buildings. When the construction or parts of it were in bad condition, (contemporary photographs show that this is particularly true for chimneys and roofs in the medieval center) vulnerability Class A is the correct designation. The buildings in massive stone tend to be Class $\mathrm{C}$. The buildings outside the center consisted of unreinforced masonry either with manufactured stone units or in massive stone. Vulnerability Classes B or C are appropriate estimations for this group.

Figure 7 illustrates the assessed damage for which we could identify the location adequately. Reports describing the losses in Sion generally point out that the damage was serious, but not disastrous. "Debris of all sorts cover the ground: Chipped chimneys, cornices, roof tiles, etc. In certain apartments parts of the ceiling caved in and the floors are covered with rubble." (Michelet 1990) Other sources write of a large number of broken store windows and cracked walls in the old part of the city (Journal et feuille d'avis du Valais, 28. 1.1946, Nouvelist Valaisan, 27.1.1946). "But one has to enter the buildings to become aware of the danger we just escaped" emphasizes Le Confedere on January 28. "The walls are cracked, the ceilings are striped [Because the gypsum fell down from the battens. Annotation from the author.] and the dishes are broken." Our investigation has shown in fact that the earthquake caused considerable loss in the city. Nevertheless, while hundreds of chimneys suffered damage or collapsed, and pieces of plaster, roof tiles and broken pieces of glass covered the roads, structural damage was rare. A few buildings showed large and extensive cracks in many or most walls; in a cinema the ceiling collapsed partly; on other houses the chimneys broke at the roofline and penetrated the roof. Since we could not fall back on systematic damage data, our reconstruction of the losses is not complete. We assume that damage of Grades 1 and 2 was omnipresent in the city without being mentioned explicitly in historical sources. Damage of Grade 3 was definitely less frequent. Nevertheless, it is difficult to estimate how complete our reconstruction is. In the case of damage Grade 3, the reconstruction is probably good, but not complete. We estimate the grade of completeness in the range of $60-80 \%$. In the case of damage Grade 2, most probably we could find only a smaller part of the actual loss. In most sources, information comes up in a general mode, without sufficient information concerning locality. Damage of Grade 1 was not an issue.

Macroseismic Intensity VII, as suggested by ECOS (2002), is the proper intensity for the city of Sion and the 1946 earthquake. Intensity of Grade VIII was clearly not reached. An important observation is that damage of Grade 3 occurred to an increased degree in the southwest. Although Figure 7 does not include all Grade 3 losses, it indicates that amplification was stronger in this part of the city, since we have no evidence that our sources cover this section better than the northern part. This finding agrees with the results of Roten et al. (2008) who performed numerical simulations of the 1946 event, using a three-dimensional structural model of the area. The grey and blue colors in the background of Fig. 7 represent the modeled amplification of ground motion indicating the factor of amplification of peak ground velocity (PGV) relative to a reference site on rock. We can see that according to Roten's model the Old Town of Sion was only slightly affected by amplification effects. To the south of the city where damage of Grade 3 is more frequent the supposed amplification from the simulation starts to increase. This pattern suggests that site-effects were of minor 


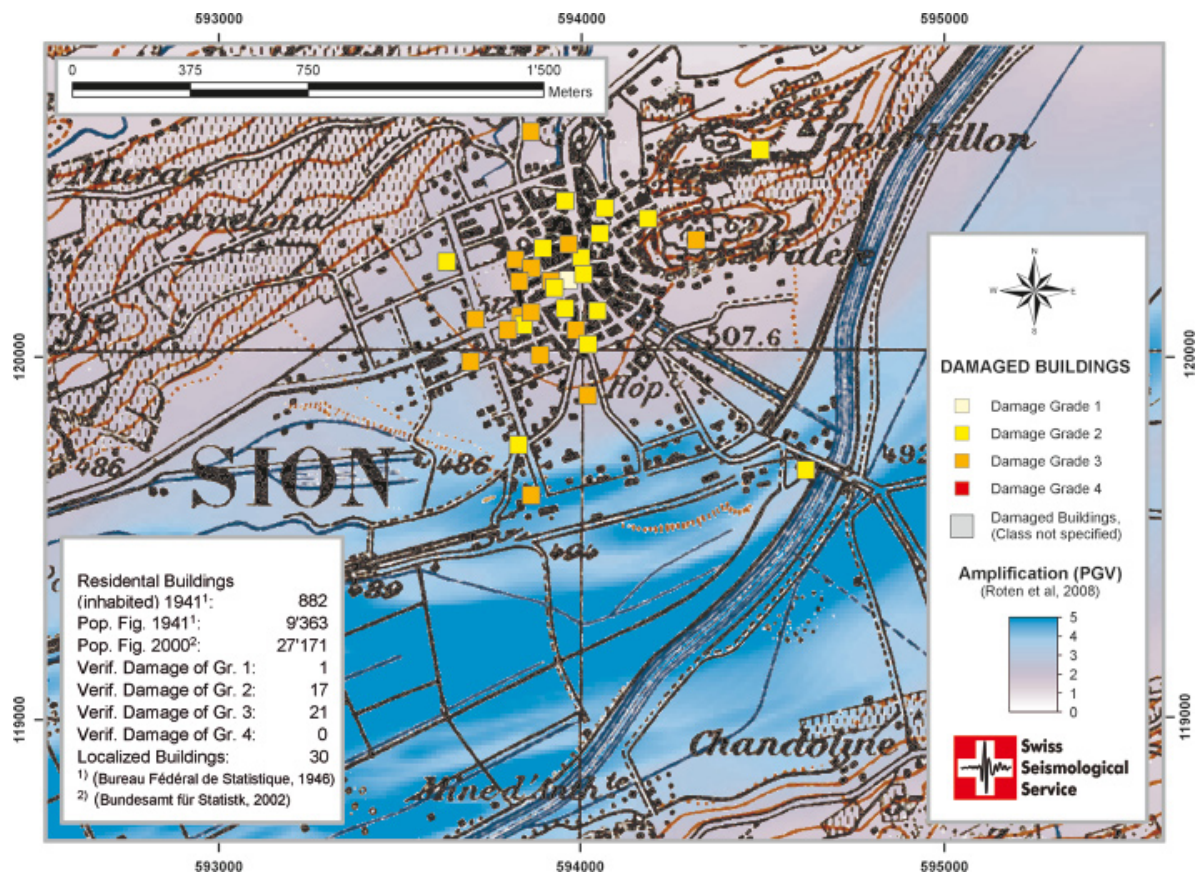

Fig. 7. Sion in its extent of 1933 including localized building damage (according to EMS 98). Since the city barely increased during the following decade, the map represents just as well the situation of 1946. The blue color indicates the modeled amplification (PGV) for the 1946 event (Roten et al. 2008). importance for the damage reported in Sion. Roten et al. (2008) show by numerical simulation that this is specifically due to the position of the event's seismic source relative to the $3 \mathrm{D}$ basin in the historical city. Thus, for other source locations amplification effects are considerable.

Figure 8 summarizes the results of our field experiments that took place in 2004 and 2005. We used H/V spectral ratios computed from ambient vibration recordings to estimate the fundamental frequency of resonance. The generally clear peaks of the $\mathrm{H} / \mathrm{V}$ spectral ratios are qualitatively expressed with the size of the circles. Figure 9 shows three typical examples of such ratios. When large, peak amplitude indicates a large impendence contrast between sediments and bedrock.

The $\mathrm{f}_{0}$ values reflect the characteristics of the Rhone valley at Sion. With a few exceptions, the distribution of the $\mathrm{f}_{0}$ values is homogeneous. Along the valley axis, in the deeper part of the basin, $\mathrm{f}_{0}$ is in the range of $0.5 \mathrm{~Hz}$ (Figure 9c). This frequency is related to the global $2 \mathrm{D}$ resonance of the Rhone valley, with sedimentary infill of up to $500 \mathrm{~m}$ (Roten et al. 2006). $\mathrm{H} / \mathrm{V}$ spectral ratios are due to these $2 \mathrm{D}$ resonances. Towards the north below the historical part of the city, $\mathrm{f}_{0}$ increases to values around $1 \mathrm{~Hz}$ (Figure 9a). To the west of site 9a, a couple of locations show pronounced peaks in the H/V ratio (Figure 9b). To the east, the rocky hills of Valère and Tourbillon limit the area with significant deposits of sediments.

Array measurements of ambient noise were conducted at several places in the Rhone valley (see Figure 8 for the sites in Sion) to constrain the shear-wave velocity of the sedimentary fill (Roten \& Fäh 2007; Roten et al. 2007). The surface sediments in the area can roughly be subdivided into two categories (Roten et al. 2007): (i) Fine lacustrine and deltaic deposits: At such sites a very shallow low-velocity layer (less than 15 meters deep) with shear-wave velocities as low as $100 \mathrm{~ms}^{-1}$ can be resolved. Below this layer, Vs ranges between 320 and $500 \mathrm{~ms}^{-1}$ until about 250 meters depth, where a strong velocity contrast occurs, and Vs increases to 650 to $800 \mathrm{~ms}^{-1}$. Shear-wave velocities in the lowest part of the sediment are in the range between 700 and 1000 ms $^{-1}$ (see Roten \& Fäh 2007, for detailed results).

(ii) Alluvial fans in the old town of Sion and in Bramois in the southeast of Sion: Apart from a shallow low-velocity layer, shear-wave velocities are much higher at these sites, with values of more than $600 \mathrm{~ms}^{-1}$ measured close to the surface.

Roten et al. (2008) suggest that there is no sharp transition between fine lacustrine and coarse alluvial deposits. The transition, however, is indicated by the quality of the H/V peaks at sites along the southern border of the historical city (Figures 8 and 9). A small impedance contrast due to the high $\mathrm{S}$-wave velocities in the alluvial fan leads to reduced amplitudes of the $\mathrm{H} / \mathrm{V}$ ratio. The fine lacustrine and deltaic deposits in the south increase the impedance contrast and therefore the amplitude of the $\mathrm{H} / \mathrm{V}$ spectral ratio.

\section{Sierre}

Historical sources agree fully, that Sierre suffered more than any other affected village or city. Numerous newspaper articles point out that Sierre presented a sad picture after the main shock. "In Sierre," wrote the Nouvelist Valaisan (27.1.1946), 


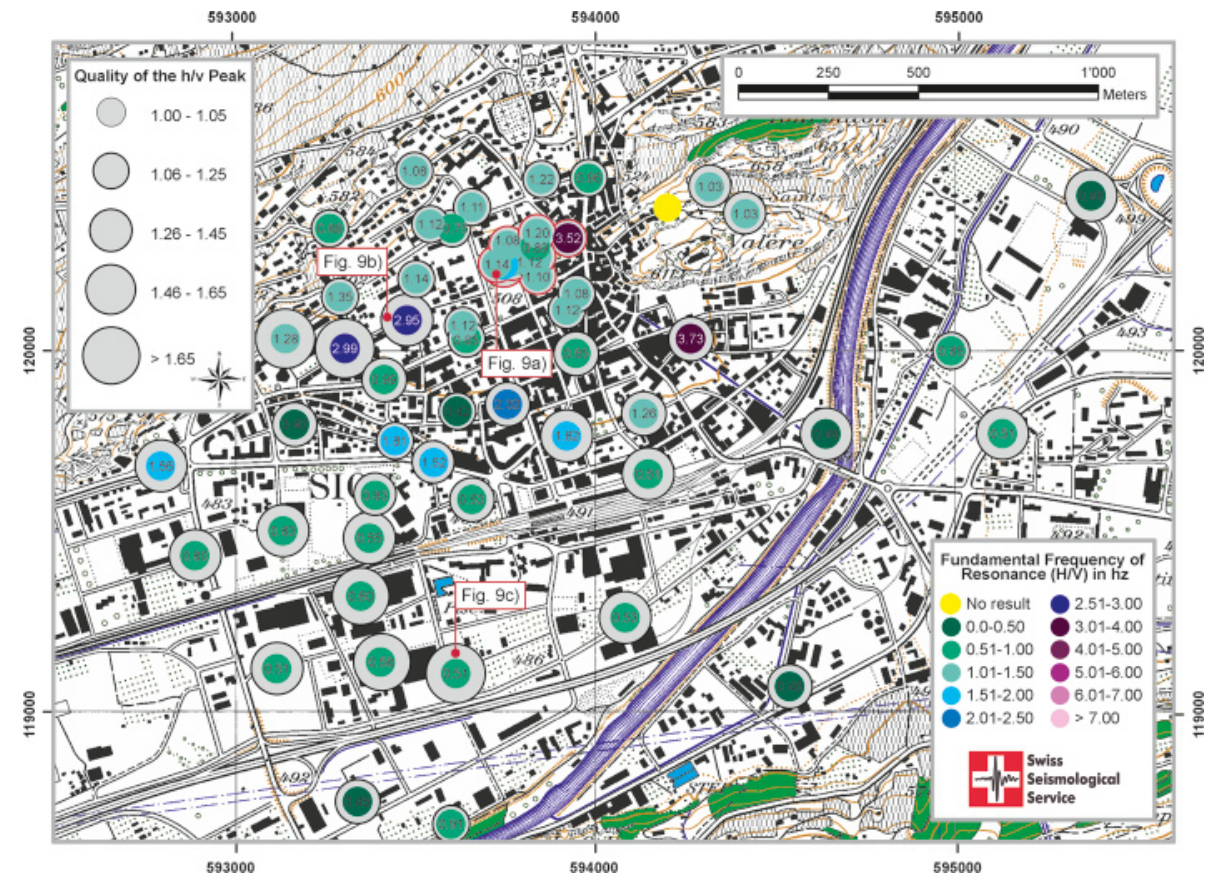

Fig. 8. Results of the field experiments in the region of Sion concerning the fundamental frequency of resonance (colored dots). The grey circles in the background indicate the quality of the peak in the H/V spectra. Large circles indicate strong impedance contrasts. Points with red outer circles are part of the different arrays that we used to determine the local S-wave velocity profiles. "everything has been displaced: the stoves, the furniture, the armoires. Ceilings broke down, the walls are cracked and slashed; outside, roof tiles fell down, and chimneys are disrupted." On January 29, the Journal de Sierre came up with information that is more detailed. "There is damage everywhere. The facades of so many houses show cracks of smaller or larger dimensions; [...], about 400 chimneys collapsed" but "the quarter that suffered most is the one of Beaulieu [...]." This was also the conclusion of Wanner and Grütter (1950) who mapped the most seriously damaged buildings in Sierre. They explicitly pointed out that the losses were concentrated in two well-defined localities. "The quarter that suffered most is situated to the west of the railway station [Quarter of Beaulieu, annotation. Authors]." Another zone of heavily damaged buildings they identified "northeast of the railway station." Figure 10 illustrates the cases of loss shown by Wanner and Grütter (1950) on the background of a 1933 map of Sierre (Siegfriedkarte, Letztausgabe, Nr. 482). The gray squares indicate the buildings identified by Wanner. The colored squares show further damaged buildings identified during our investigation.

Apart from the structures identified by Wanner \& Grütter (1950), we found independent information about 45 damaged houses, but could locate only 13 of them properly. Almost all are identical with buildings mentioned by Wanner \& Grütter (1950). It is as likely as not that many of the buildings not located also correspond to the damaged buildings he mapped. Comparison of damaged objects identified by us as well as by Wanner showed that what he mentioned as "the buildings that have suffered the largest damage" (Wanner \& Grütter 1950) sustained damage of Grades 3 to 4 . Nevertheless, we marked the objects in Figure 7 conservatively so as not to overestimate our accuracy.
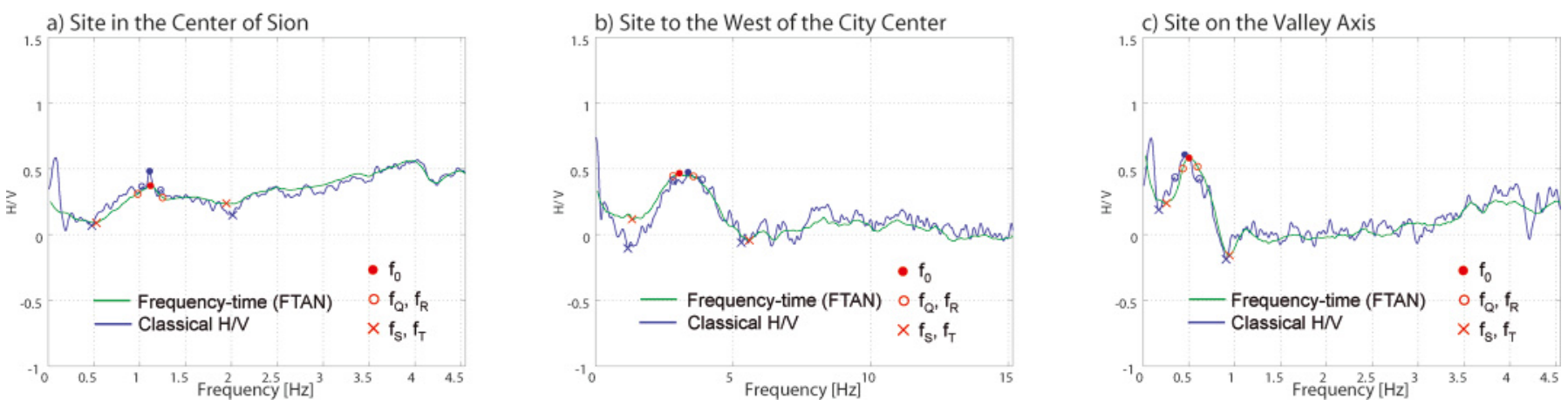

Fig. 9. Three examples of H/V peaks for sites in Sion. The position of the corresponding sites is indicated in Figure 8 by letters. 


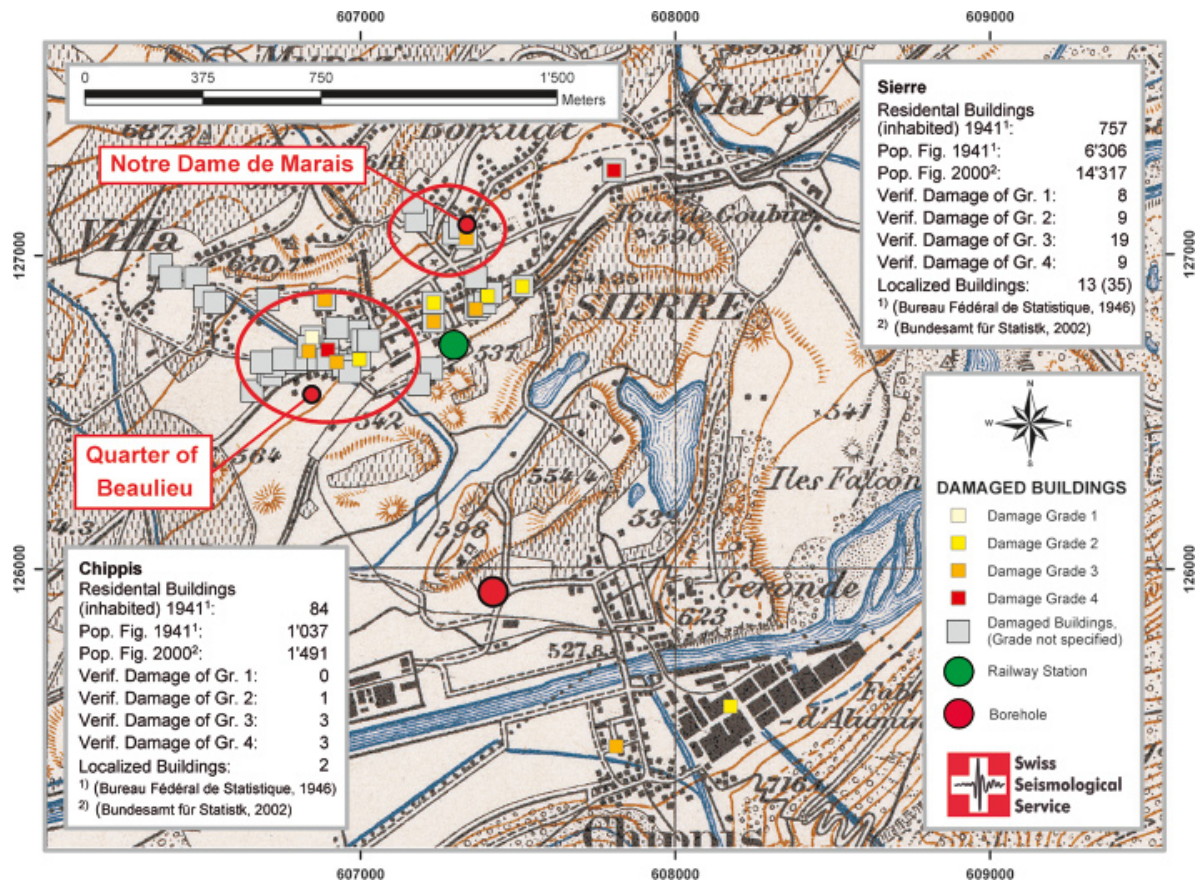

Fig. 10. Sierre in its extent of 1933 including localized building damage (according to EMS 98). As in the case of Sion, Sierre developed only marginally in the years before the earthquake. Besides localized and assessed buildings, the figure includes buildings mentioned by Wanner \& Grütter (1950) as the ones that suffered "most" (gray squares).
Wanner \& Grütter (1950) attribute the concentration of losses in the two well-defined areas to building vulnerability and ground conditions. They mention that the buildings at the Beaulieu quarter were built at the beginning of the $20^{\text {th }}$ century, at a time where "[...] one used quicklime for the construction [...]", which has weakened the construction with respect to ground shaking. In contrast, neighboring buildings built in reinforced concrete, he remarks, have resisted the "shocks without any important damages." (Wanner \& Grütter 1950). We have not much information concerning building vulnerability in the Beaulieu quarter since in the last 60 years much has changed. Nevertheless, vulnerability Class B is probably a reasonable assumption here. Most of the affected buildings we have located and assessed in Sierre belong to this class. A few others, mainly historic buildings like the Church of Notre Dame de Marais (damage Grade 3), include elements that belong in vulnerability Class A. Buildings of vulnerability Class C showed only minor damage. The height of the buildings varied from two to four stories in Sierre in that time. Over all, building vulnerability is hardly the determining factor in forming the damage field as shown, even though our knowledge is limited concerning this matter. Like Wanner \& Grütter (1950), we assume that ground conditions had a crucial impact on the damage distribution. They mention that the zone of damage to the west is mostly located on an alluvial cone. The affected area to the northeast was in earlier days an area of swampland, according to their comments (Wanner and Grütter, 1950). A hint for this is also found in the name of the mentioned Church of Notre Dame de Marais, since "marais" is the French word for swamp or marshland. Nevertheless, the geology of the Sierre region is much more complex than Sion's. Sierre is located at least partly on a rockslide debris deposit of about 1000-2000*10 $10^{6}$ cubic meters (Abele 1974) that characterizes the infill of the valley as well as the geomorphologic situation.

According to Burri (1954) this landslide occurred after the glacier of the last ice age retreated. However, later on the glacier passed over again and left its mark (ibid.). On the northern slope of the valley, where the historic village of Sierre is located, debris of alluvial cones of variable thickness from creeks entering the main valley partly covers the material of the rockslide. In conformance with Wanner \& Grütter (1950), the map of Burry (Figure 11) shows that the Beaulieu quarter is located on this alluvial cone. The eastern part of Sierre is built partly on the material of the landslide and partly on fluviatile sediments. The part of Sierre south of the railway station out to the village of Chippis is built on alternating sediment layers deposited by the landslide and the Rhone River. Borehole information available north of the river (about in the valley center of the valley, see Figure 10) shows landslide material at a depth of 50 meters (Strassenbauamt, 2007). We assume that this deposit material exists also at greater depth. Rosselli (2001) estimated the maximum thickness of the whole infill to about 330 meters.

As in the Sion region, we performed in Sierre many ambient vibration H/V measurements in 2004 and 2006. In total, we recorded ambient vibration at 115 locations. Figures 12 and 13 show the results of these experiments. In contrast to the results of Sion, most of the H/V spectral ratios computed for the Sierre site show two peaks: the first in the frequency range between 0.7 and $1.9 \mathrm{~Hz}$ (Fig. 9) and the second between 1.8 and about $10 \mathrm{~Hz}$ (fig 10). In general the latter peak is better developed, which is visible in Figs. 12 and 13 in the grey circle. 


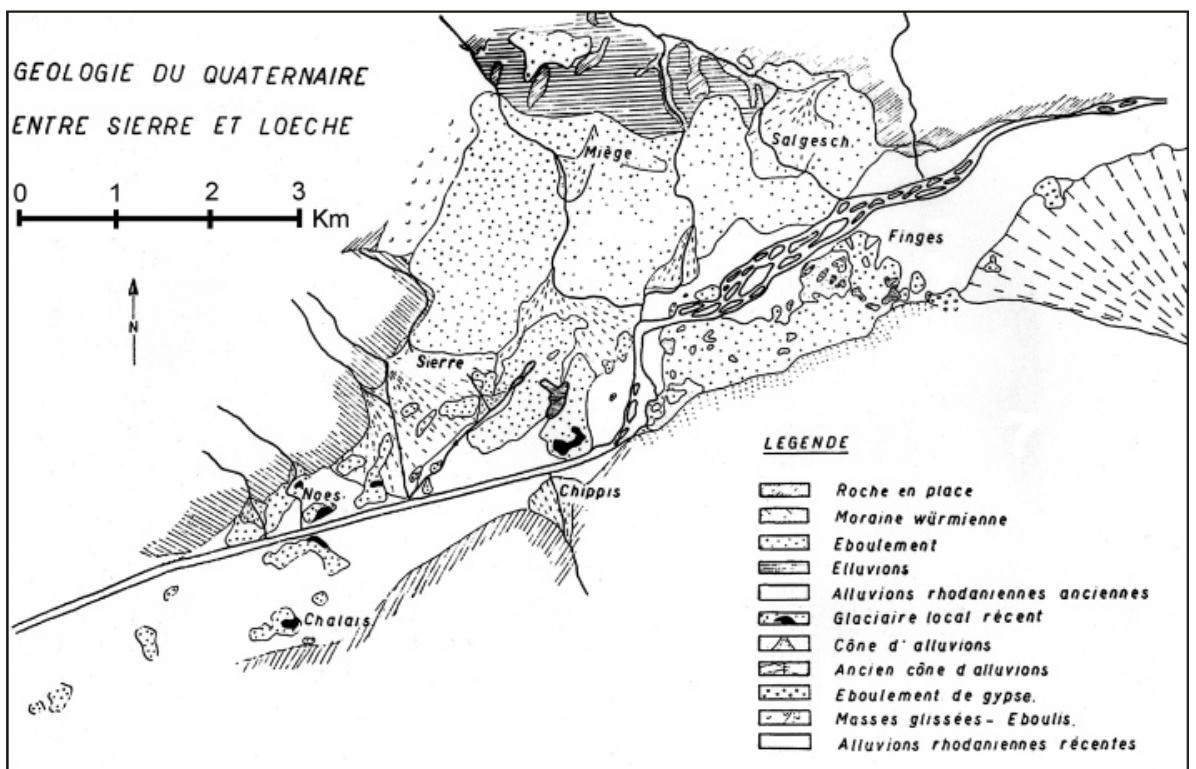

Fig. 11. Geological situation of the Sierre region (Burri 1954).
We interpret the lower peak as the resonance frequency of the total infill of the valley. Using the simple equation $\mathrm{f}_{0}=\mathrm{V}_{\mathrm{s}} / 4 \mathrm{~h}$ and a sediment thickness ( $\mathrm{h}$ ) of about 300-330 meters, the resulting average shear wave velocities are about $900-1000 \mathrm{~m} / \mathrm{s}$ (with $\mathrm{f}_{0}=0.75-0.8 \mathrm{~Hz}$ ). This is a reasonable value for the shear wave velocity in sedimentary deposits, as at the Sierre site.

The peak at higher frequency shown in Figure 13 is due to the impedance contrast between a surface layer with unconsolidated sediments of variable thickness and composition, and the compact debris deposit of the rockslide. Figure 14 shows three typical examples of H/V spectral ratios. For much of Sierre, the fundamental frequency of resonance of this surface layer $(2-6 \mathrm{~Hz})$ is in the range of possible eigenfrequencies of buildings with two to four stories, extant in Sierre then. Note that the better quality of the peak for sites in the two areas with highest damage indicates a stronger impedance contrast compared to other locations. This pattern suggests an increased amplification and can be interpreted as a possible site-effect during the 1946 earthquake.

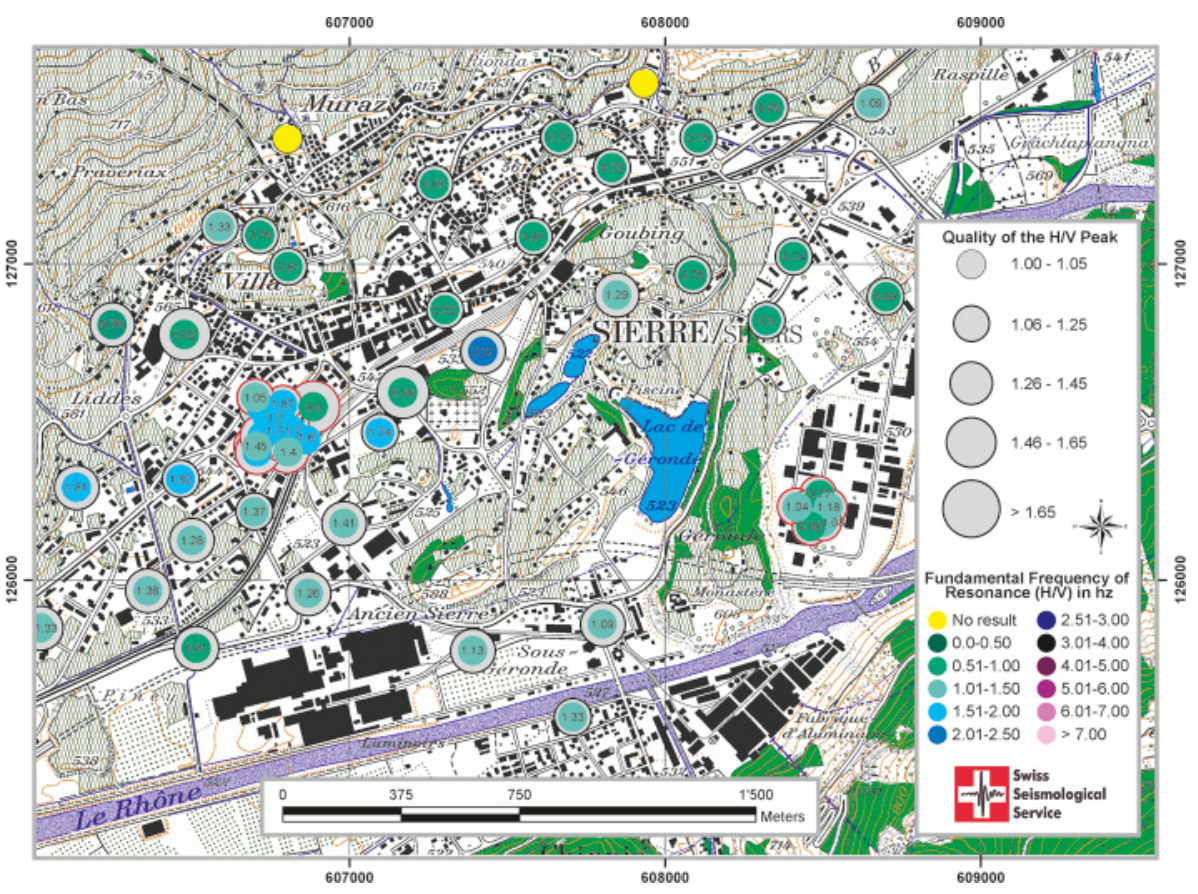

Fig. 12. Results of the field experiments concerning the fundamental frequency of resonance. Sierre shows almost area-wide two peaks in the $\mathrm{H} / \mathrm{V}$ spectral ratios. In this figure, we show the peak of lower frequency. Yellow points might indicate a rock site. Points with red outer circles are part of the different arrays used to determine the local S-wave velocity profile. 


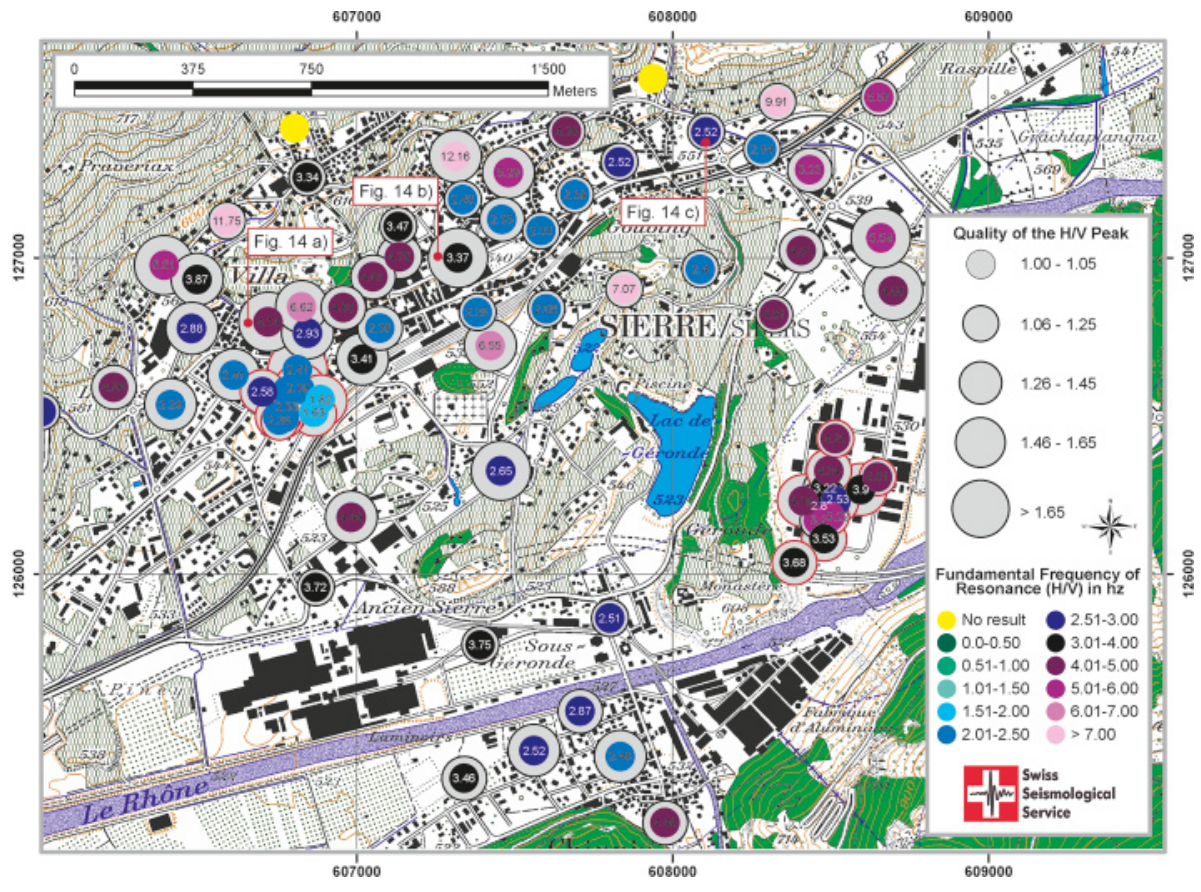

Fig. 13. Results of the field experiments concerning the fundamental frequency of resonance. Sierre shows almost area-wide two peaks in the $\mathrm{H} / \mathrm{V}$ spectral ratios. The figure shows the peak at higher frequency. Yellow points might indicate a rock site. Points with red outer circles are part of the different arrays used to determine the local $\mathrm{S}$-wave velocity profile.
To better characterize this surface layer at the Beaulieu quarter, we performed ambient vibration array measurements. The goal of this experiment was to achieve an S-wave velocity profile of the site, which should help to characterize thickness and velocity of the subsoil. Due to high building density, we moved the array slightly west of the area of greatest damage in 1946 (see Figure 13). We analyzed phase velocities of fundamental and higher mode Rayleigh and Love waves with high-resolution beam forming method as outlined in Fäh et al. (2008).

The experiment led to the peculiar results shown in Figure 15. H/V spectral ratios show clear peaks around the frequency of $2 \mathrm{~Hz}$ (Figure 15a), indicating the fundamental frequency of resonance in a surface layer with low S-wave velocities. To develop such a strong peak in the $\mathrm{H} / \mathrm{V}$ ratio, we expected $\mathrm{S}$-wave velocity in the range $200-300 \mathrm{~m} / \mathrm{s}$ for the surface layer. It was, however, not possible to obtain phase velocity curve seg- ments of the fundamental mode Rayleigh and Love waves in the frequency range up to $10 \mathrm{~Hz}$ with phase velocities smaller than $700 \mathrm{~m} / \mathrm{s}$ (Figure 15b,c). We do recognize higher modes of surface waves which most probably sample the deeper rockslide debris layers of higher velocities in the range $800-1300 \mathrm{~m} / \mathrm{s}$. This finding indicates that standing waves of a $2 \mathrm{D}$ or $3 \mathrm{D}$ resonance might dominate the wave field at the lower frequency around $\mathrm{f}_{0}$. The peak in the H/V spectral ratio would then represent the fundamental frequency of resonance of two- or three-dimensional eigenvibrations of the sedimentary layer. Within the city area, the variability of the fundamental frequency of resonance in the surface layer over rather short distances might also indicate possible $2 \mathrm{D}$ or $3 \mathrm{D}$ resonance phenomena, particularly in those areas most affected.

Ambient vibration array methods can only map the velocity structure at sites not subject to global $2 \mathrm{D}$ or $3 \mathrm{D}$ resonance
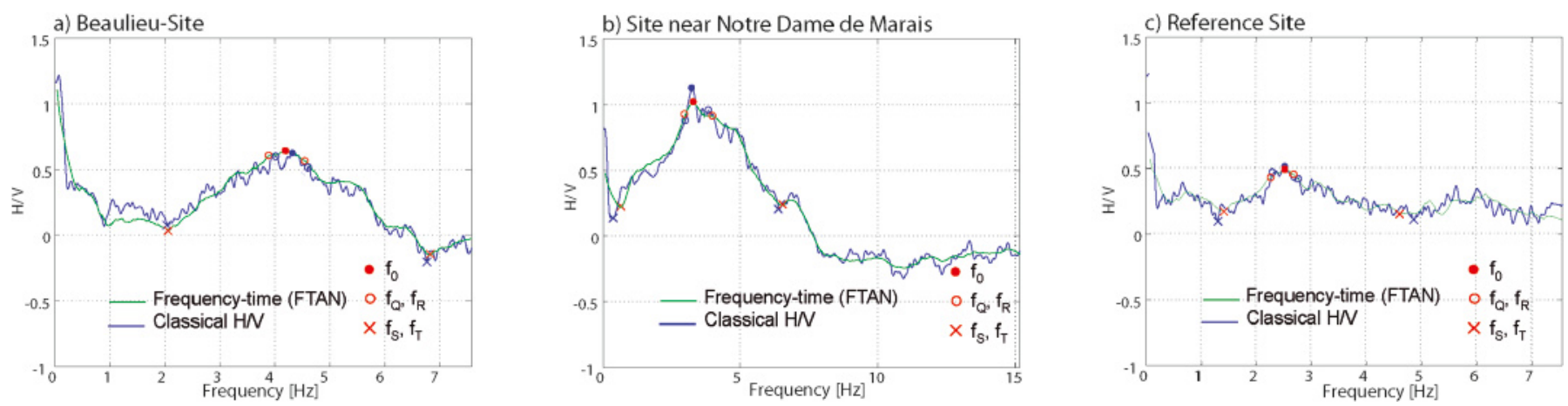

Fig. 14. Three examples of H/V peaks for sites in Sierre. The position of the corresponding sites is indicated in Figure 13 by letters. While Figures a) and b) are related to sites where heavy damage occurred, Figure c) is associated with a location with no considerable damage.

436 S. Fritsche \& D. Fäh 
15 a) Central Station of Array: HN Spectral Ratio

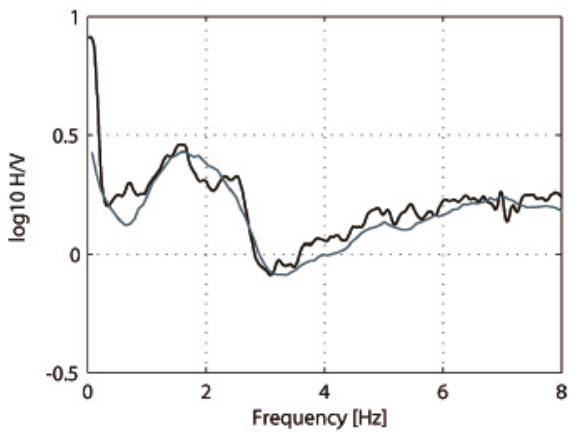

15 b) Dispersion Curve (Raleigh Waves)

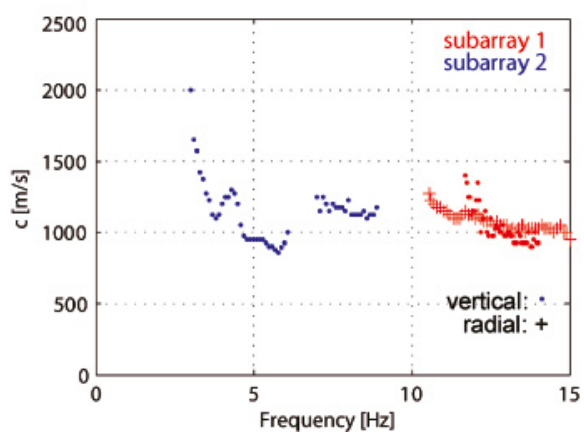

15c) Dispersion Curce (Love Waves)

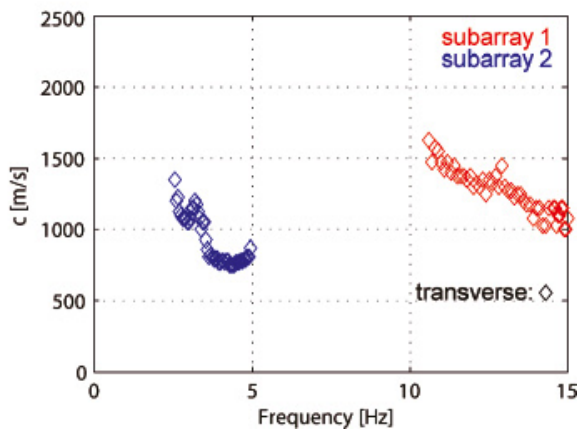

Fig. 15. a) H/V spectral ratio obtained for the central station of the array near the Beaulieu Quarter. The black line is the result from classical polarization analysis in the frequency domain, and the grey line was obtained with a method based on frequency-time analysis. Dispersion curve segments for Rayleigh (b) and Love waves (c) obtained from ambient vibration array measurements. The subarrays are shown in different colors. Vertical: analysis of the vertical components; radial: analysis of the radial components; transverse: analysis of the transverse components.

phenomena. The method was successful, however, for the second array shown in Figure 13 (to the west of Lac de Géronde). The inverted structural model obtained from the phase velocity curves consists of three layers: a surface of $30 \mathrm{~m}$ with an average $\mathrm{S}$-wave velocity of about $400 \mathrm{~m} / \mathrm{s}$, a second of about $50 \mathrm{~m}$ thickness and $800 \mathrm{~m} / \mathrm{s} \mathrm{S}$-wave velocity, and a third with S-wave velocities in the range $1300-1700 \mathrm{~m} / \mathrm{s}$.

\section{Conclusions}

Our aim was to reconstruct the damage field of the 1946 earthquake series in the middle Valais region and discover whether site-effects had an evident impact on its characteristics. The series started on January 25, 1946 with a main shock $(\mathrm{Mw}=6.1$ according ECOS-02, Mw 5.8 according to Bernardi et al., 2005) followed by several hundred aftershocks until the end of the nineteen forties. Among them were three in the range of $\mathrm{Mw}=5.1-6(\mathrm{ECOS}-02,2002)$. In the first part of the study, we considered the affected region without geographic limits, but focused in the second part on the cities of Sion and Sierre.

Since a contemporary damage assessment was not at hand in its original form, our results concerning the first task rely on unsystematic data. It is unlikely that further results can be achieved as long as the original documents of the damage assessment are untraceable. The few known key data from the assessment allowed us to describe the damage field systematically at the level of the Valaisan districts. Comparison of the average loss in CHF per district and the percentage of buildings located on deposit sites of the extensive Rhone Valley per district showed some correlation between these two values. Districts with heavy settlement on the bottom of the Rhone Valley show a higher average loss per building. This is a strong indication that the ground of the valley floor provoked siteeffects resulting in higher observed intensity. A further reason for the increased intensity is the building stock of the valley floor that tends to be more vulnerable when compared with buildings common on the mountainside. We thus conclude that the characteristics of the damage field are a consequence of a combination of site-effects and building vulnerability.

Besides building damage we were able to locate a large number of different secondary effects from rock falls, landslides, and avalanches to terrain changes and effects on water springs. Most are related to the main shock of January 25; the large rock fall of several millions $\mathrm{m}^{3}$ at the Ravylhorn, however, was triggered by the aftershock of May 30. Due to the fault location, secondary effects were more frequent on the northern slope of the Rhone valley. Not surprisingly many observations concentrate in the immediate vicinity of the presumed epicenter. However, many secondary effects of considerable extent occurred at distances up to $40 \mathrm{~km}$.

Proceeding to the second part of the study, we conclude that the outcomes for the cities of Sion and Sierre differ in many respects. For Sion we showed that intensity VII was clearly not exceeded. Damage was substantial and omnipresent, but structural failure was rare. Field experiments with respect to the fundamental frequency of resonance showed that ground amplification during an earthquake probably occurs in a frequency range lower than the resonance frequencies of the city's buildings. According to the numerical simulation performed by Roten et al. (2008), peak ground velocities obtained from the simulation of the 1946 main shock yield no large amplification in old Sion. This is specifically due to the position of the seismic source of the 1947 event relative to the 3D basin in the historical city. For other source locations amplification effects can be large.

In contrast, the Sierre site reached intensity VIII. Damage of Grade 3 was frequent and damage of Grade 4 not rare. Our investigation has shown that in particular two areas showed concentrated, serious damage (Quarter of Beaulieu and the area of Notre Dame de Marais). We have strong indications that damage there is related to site conditions. One of the sites is former swampland while an alluvial cone characterizes the other. For both, field experiments have shown that the impedance contrast seems to be stronger than for most other sites in Sierre. The fundamental frequency of resonance in the surface layer, however, 
varies considerably within the investigated area. It is within a range of relevance for the building stock, not only for these two areas of increased damage, but also for almost the whole city. Further investigation based on ambient vibration array measurements showed peculiar results that are likely due to local $2 \mathrm{D}$ or $3 \mathrm{D}$ resonance phenomena. At the same time, a $2 \mathrm{D}$ or $3 \mathrm{D}$ resonance effect would reasonably explain the irregular distribution of damage in Sierre. We conclude that ground conditions there show characteristics that favor site amplification effects. When compared with the old town of Sion, the building stock of Sierre has changed more since the nineteen forties, especially in the two areas with high loss. The influence of the building stock on the loss is thus difficult to rate. More investigations toward this topic would be desirable for the case that the missing damage assessment someday reappears. Furthermore, the finding of the latter would open completely new fields for additional siteeffect studies in the whole Valais region.

\section{Acknowledgements}

This paper was prepared while working for a $\mathrm{PhD}$ project at the Swiss Federal Institute of Technology in Zurich. Many people have contributed to its success. We would like to thank all of them. Special thanks go to the reviewers Nazario Pavoni and Massimiliano Stucchi as well as to our English editor Dr. Kathleen J. Jackson.We gratefully acknowledge the financial support of the Swiss National Science Foundation (project number: 205121-100510).

\section{REFERENCES}

\section{HISTORICAL SOURCES}

Bund, February 2, 1946: Heisse Quellen, unterirdische Flüsse und Erdbeben. Newspaper article.

Bureau fédéral de statistique, 1946: Canton du Valais. Recensement fédéral de la population 1er décembre 1941. Vol. 16. Statistiques de la Suisse, fasc. 169. Berne.

Journal de Sierre, January 29, 1946: Le terrible tremblement de terre. Newspaper article.

Journal et feuille d'avis du Valais, January 28, 1946: Après le tremblement de terre. Newspaper article.

Lac Souterrain de St-Leonard, Géologie et histoire. 12. Jan. 2008: http://www. lac-souterrain.com/.

Le Confedere, January 28, 1946: Après un tremblement de terre. Newspaper article.

Michelet, H. 1990: Le Valais. 1475-1634. Récit des événements et aperçu des grands problèmes valaisans de l'époque. Saint-Maurice. Editions Rhodaniques. 1982-1990.

Nouvelliste Valaisan, January 27, 1946: Le violent tremblement de terre ressenti dans toute la Suisse, en France et en Italie. Newspaper article.

Walliser Nachrichten, May 14, 1946: Folgen des Erdbebens. Newspaper article.

Oberländer Tagblatt, January 28, 1946: Die Folgen des Erdbebens. Newpaper article.

StAW (Staatsarchiv des Kantons Wallis): Protocoles des séances du Conseil d'État, 1946. 1101, vol. 97, 1945-1946.

\section{SCIENTIFIC ARTICLES}

Abele, G. 1974: Bergstürze in den Alpen: Ihre Verbreitung, Morphologie und Folgeerscheinungen. Wissenschaftliche Alpenvereinshefte. Heft 25 München.
Bernardi, F., Braunmiller, J. \& Giardini, D. 2005: Seismic Moment from Regional Surface-Wave Amplitudes: Applications to Digital and Analog Seismograms. Bulletin of the Seismological Society of America 95 (2). 408-418.

BRGM, EDF \& IRSN. 2005: SisFrance. 10. Jan. 2008: http://www.sisfrance. net.

Burri, M. 1954: La Géologie du Quartenaire aux environs de Sierre. Bulletin Société vaudoise des Sciences naturelles, vol. 66, no. 289. 141-152.

Capon, J. 1969: High-resolution frequency-wave number spectrum analysis, Proceedings IEEE, 57(8). 1408-1418.

ECOS-02, 2002: Earthquake Catalogue of Switzerland. Swiss Seismological Service. http://www.seismo.ethz.ch.

Fäh, D., Stamm, G. \& Havenith, H.-B. 2008: Analysis of three-component ambient vibration array measurements. Geophysical Journal International, 172. 199-213.

Fäh, D., Giardini, D., Bay, F., Bernardi, F., Braunmiller,J., Deichmann, N., Furrer, M., Gantner, L., Gisler, M., Isenegger, D., Jimenez, M.J., Kästli, P., Koglin, R., Masciadri, V., Rutz, M., Scheidegger, C., Schibler, R., Schorlemmer, D., Schwarz- Zanetti, G., Steimen, S., Sellami, S., Wiemer, S., \& Wössner, J. 2003: Earthquake Catalogue Of Switzerland (ECOS) And The Related Macroseismic Database. Eclogae Geologicae Helvetiae, Swiss Journal of Geosciences, 96. 219-236.

Fäh D., Kind F., \& Giardini, D. 2001: A theoretical investigation of average H/V ratios. Geophysical Journal International, 145. 535-549.

Fritsche, S. 2008: Large Historical Earthquakes in Switzerland. Multidisciplinary Studies on Damage Fields and Site-Effects Ph.D. thesis no 17710 , ETH Zurich.

Fritsche, S., Fäh, D., Gisler, M., \& Giardini, D. 2006: Reconstructing the Damage Field of the 1855 Earthquake in Switzerland: Historical Investigations on a Well-documented Event. Geophysical Journal International, 166. 719-731.

Gisler, M., Fäh, D. \& Deichmann, N. 2004: The Valais Earthquake of December 9,1755. Eclogae Geologicae Helvetiae -Swiss Journal of Geosciences, 97. 411-422.

Grünthal, G. (Ed.) 1998: European Macroseismic Scale 1998. Cahiers du Centre Européen de Geodynamics et de Séismologie. Vol. 15. Conseil de L'Europe. Luxembourg.

Kind, F., Fäh, D., P. \& Giardini, D. 2005: Array measurements of S-wave velocities from ambient vibrations. Geophysical Journal International, 160. 114-126.

Mariétan, I. 1946: Le tremblement de terre du 25 Janvier 1946. Bulletin de la Murithienne - Société Valaisanne des sciences naturelles, fasc. 63. 70-87.

Mariétan, I. 1947: Le tremblement de terre du 25 Janvier. Almanach du Valais. 53-55.

Montadon, F. 1946: Les trois récents séismes du Valais central. Revue pour l'étude des calamités. Tome IX, fascicule 24. 50-68.

Montadon, F. \& Staub, W. 1946: Sur la cause des tremblements de terre du Haut-Valais. Globe, Organe de la société de Géographie de Genève. Tome 85.1-21.

Rosselli, A. 2001: Modélisation gravimétrique bi- et tridimensionnelle du substratum rocheux des vallées alpines. PhD thesis. Université de Lausanne.

Roten, D.,Fäh, D., Olsen, K.B., \& Giardini, D. 2008: A comparison of observed and simulated site response in the Rhone valley. Geophysical Journal International, 173(3) 958-978.

Roten, D. \& Fäh, D. 2007: A combined inversion of Rayleigh wave dispersion and 2-D resonance frequencies. Geophysical Journal International, 168(3). 1261-1275.

Roten, D. 2007: Site-effects in the Rhone valley analysed by ambient noise, weak motion records and numerical simulations. Ph.D. thesis, ETH Zurich.

Roten, D., Fäh, D., Cornou, C., \& Giardini, D. 2006: Two-dimensional resonances in Alpine valleys identified from ambient vibration wavefields. Geophysical Journal International, 165(3). 889-905.

Siegfriedkarte, Erstausgabe. Elektronisches Kartenmaterial. Topographischer Atlas der Schweiz. Swisstopo (Ed.). Wabern, Bundesamt für Landestopographie, 2003a. Kartenblätter Nr. 486, Sion, 1890; 1:50'000.

Siegfriedkarte, Letztausgabe. Elektronisches Kartenmaterial. Topographischer Atlas der Schweiz. Swisstopo (Ed.). Wabern, Bundesamt für Landestopographie, 2003b. Kartenblätter Nr. 476, Monthey, 1939; Nr. 477,

438 S. Fritsche \& D. Fäh 
Diablerets, 1939; Nr. 481, St. Léonard, 1933; Nr. 482, Sierre, 1933; Nr. 483, St. Maurice, 1933; Nr. 485, Saxon, 1932; Nr. 486, Sion, 1933; Nr. 487, Vissoie, 1934; Nr. 496, Visp, 1934; Nr. 497, Brig, 1934; Nr. 526, Martigny, 1933; Nr. 527, Lourtier, 1933. 1:50'000.

Strassenbauamt des Kantons Wallis. 2007: Borehole information. Unpublished Database.

Swiss Earthquake Commission: Jahresberichte des Erdbebendienstes der Schweiz. 1939-56: Von E. Wanner. Zürich.

Swiss Map 25: Elektronische Kartenmaterial. - Wabern: Bundesamt für Landestopographie, Stand 2000. Kartenblätter Nr. 1287, Sierre, 1992; Nr. 1306, Sion, 1992.1:25'000.
Wanner, E. 1955: Die Lage der Erdbebenherde im Mittelwallis. Eclogae Geologicae Helvetiae, 48. Nr. 2. 245-255.

Wanner, E. \& Grütter, M. 1950: Edude sur les répliques de tremblement de terre du Valais, de 1946 à 1950. Bulletin de la Murithienne, fascicule LXVII. 24-41.

Manuscript received April 17, 2008

Revision accepted November 20, 2009

Published Online first December 15, 2009

Editorial Handling: S. Bucher 